\title{
A framework for modeling adaptive forest management and decision making under climate change
}

\author{
Rasoul Yousefpour $^{1}$, Christian Temperli ${ }^{2,3}, \underline{\text { Jette Bredahl Jacobsen }}^{4}$, Bo Jellesmark Thorsen $^{4}$, Henrik Meilby $^{5}$, Manfred J. Lexer $^{6}$, \\ Marcus Lindner $^{7}$, Harald Bugmann $^{2}$, Jose G. Borges $^{8}$, ,oão H. N. Palma $^{8}$, Duncan Rav $^{9}$, Niklaus E. Zimmermann $^{2,3}, \underline{\text { Svlvain Delzon }}^{2}$

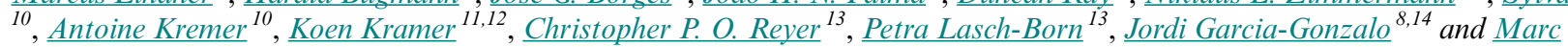 \\ $\underline{\text { Hanewinkel }}^{l}$
}

ABSTRACT. Adapting the management of forest resources to climate change involves addressing several crucial aspects to provide a valid basis for decision making. These include the knowledge and belief of decision makers, the mapping of management options for the current as well as anticipated future bioclimatic and socioeconomic conditions, and the ways decisions are evaluated and made. We investigate the adaptive management process and develop a framework including these three aspects, thus providing a structured way to analyze the challenges and opportunities of managing forests in the face of climate change. We apply the framework for a range of case studies that differ in the way climate and its impacts are projected to change, the available management options, and how decision makers develop, update, and use their beliefs about climate change scenarios to select among adaptation options, each being optimal for a certain climate change scenario. We describe four stylized types of decision-making processes that differ in how they (1) take into account uncertainty and new information on the state and development of the climate and (2) evaluate alternative management decisions: the "no-change," the "reactive," the "trend-adaptive," and the "forward-looking adaptive" decision-making types. Accordingly, we evaluate the experiences with alternative management strategies and recent publications on using Bayesian optimization methods that account for different simulated learning schemes based on varying knowledge, belief, and information. Finally, our proposed framework for identifying adaptation strategies provides solutions for enhancing forest structure and diversity, biomass and timber production, and reducing climate change-induced damages. They are spatially heterogeneous, reflecting the diversity in growing conditions and socioeconomic settings within Europe.

Key Words: behavioral adaptation; Europe; forest management; knowledge management; mathematical programming; process-based models; spatial planning

\section{INTRODUCTION}

Climate change is a challenge for forestry because of the direct impacts on forest ecosystems and the long time span between management decisions and the results obtained. Therefore, adaptive forest management (AFM) in a changing climate is at the core of contemporary forest management research (Bolte et al. 2009, Temperli et al. 2012, Yousefpour et al. 2012). However, several challenges have to be dealt with and flexible AFM strategies need to be defined because there is uncertainty about the degree of climate change (Allen et al. 2000, IPCC 2014), the influence on disturbance regimes, the speed with which changes happen, and the response of forests to the changing climate (Lindner et al. 2014). Furthermore, decision makers may have their own perceptions and beliefs about the degree of change (and not the causes of climate change being anthropogenic or not), and they adjust decisions accordingly (Yousefpour et al. 2014). Beliefs refers here not to the cause of climate change and whether it is anthropogenic or not, but to the degree to which it may happen. European forest landscapes vary strongly with respect to their socioeconomic context and bioclimatic conditions.
Consequently, there is no one-size-fits-all solution for adaptive decision-making problems, and complex AFM decision-making problems are not easy to solve. In this contribution, we present a framework for locally applicable AFM solutions.

Projections of the magnitude and speed of climate change are constantly being updated and reinterpreted (Giorgetta et al. 2013, IPCC 2014). New information continuously flows to decision makers, affecting their beliefs and expectations about climate change. Behavioral decision research has started to investigate how forest owners relate to new knowledge, how they form and change perceptions, and how this affects their decision-making behavior (Blennow et al. 2012, 2016). Similarly, the impacts of climate change on the state and functioning of forest ecosystems and their components is the subject of a growing number of studies (Allen et al. 2010, Lindner et al. 2014, Hickler et al. 2015). The interaction between management actions and climate change impacts on forests is the focus of a growing body of empirical studies as well as advanced simulations (Temperli et al. 2012, Reyer et al. 2014, Schou et al. 2015, Trasobares et al. 2016).

${ }^{1}$ Forestry Economics and Forest Planning, University of Freiburg, Germany, ${ }^{2}$ Forest Ecology, Institute of Terrestrial Ecosystems, Department of Environmental Systems Science, ETH Zürich, Switzerland, ${ }^{3}$ Swiss Federal Institute for Forest, Snow and Landscape Research WSL, Birmensdorf, Switzerland, ${ }^{4}$ Department of Food and Resource Economics and Centre for Macroecology, Evolution and Climate, University of Copenhagen, Denmark, ${ }^{5}$ Department of Food and Resource Economics, University of Copenhagen, Denmark, ${ }^{6}$ Institute of Silviculture, University of Natural Resources and Life Sciences BOKU, Vienna, Austria, ${ }^{7}$ Resillience Programme, European Forest Institute, Bonn, Germany, ${ }^{8}$ Forest Research Centre, School of Agriculture, University of Lisbon, Portugal, ${ }^{9}$ Forest Research, Roslin, Midlothian, UK, ${ }^{10}$ BIOGECO, INRA University of Bordeaux, Cestas, France, ${ }^{11}$ Wageningen Environmental Research, ${ }^{12}$ Wageningen University, The Netherlands, ${ }^{13}$ Potsdam Institute for Climate Impact Research (PIK), Member of the Leibniz Association, Potsdam, Germany, ${ }^{14}$ Forest Sciences Centre of Catalonia (CEMFOR-CTFC), Solsona, Spain 
Fig. 1. Case studies representing the diversity of European forests (Source: European Forest Institute).

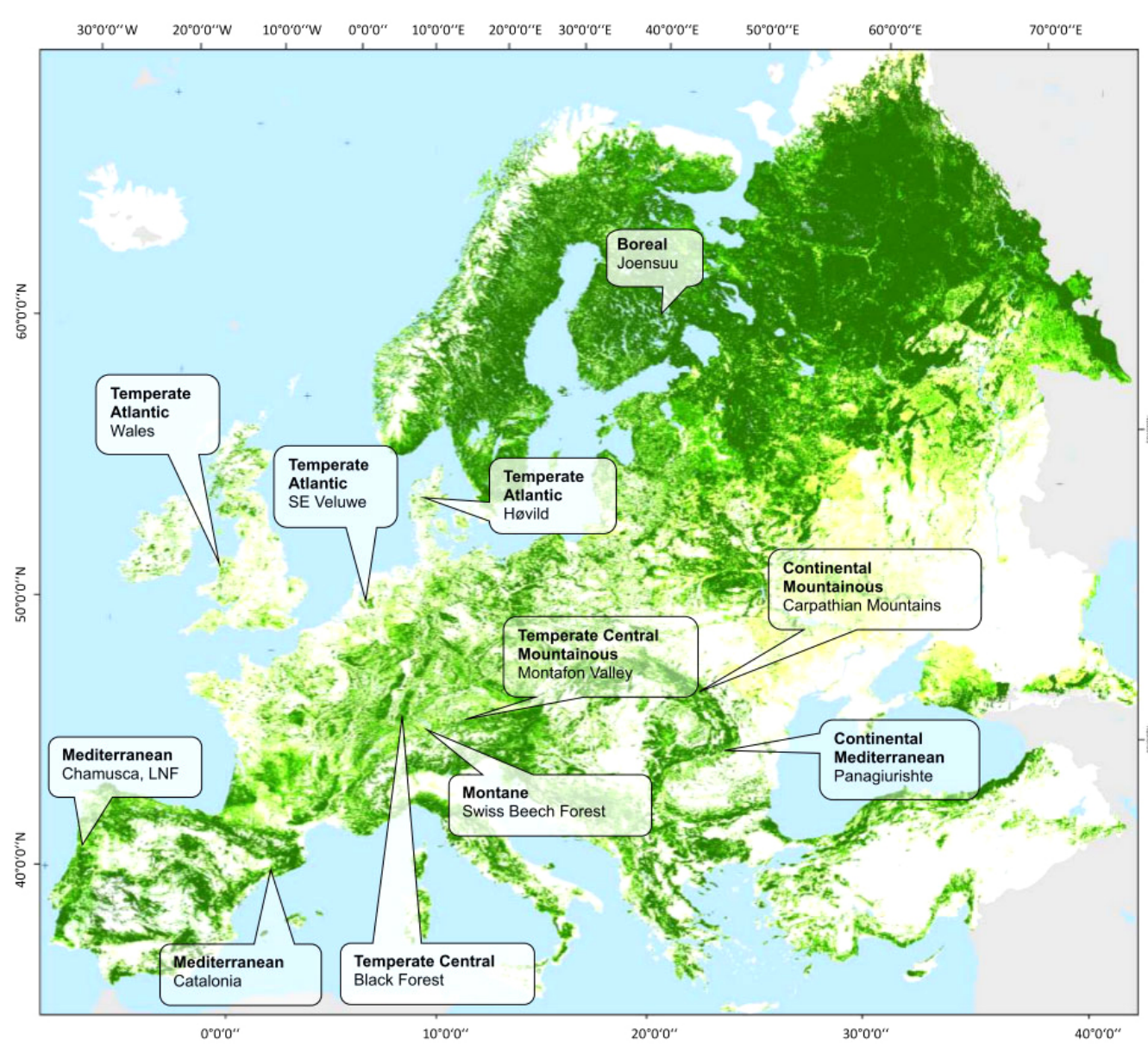

Proportion of forest from land area (\% at $1 \mathrm{~km} \times 1 \mathrm{~km}$ resolution)

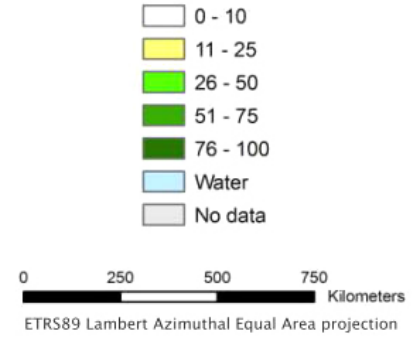

Data Source Earth observation data: EU27, Al, BA CH, HR, ME, MK, NO, RS, TR: Forest/non.forest map 2006 (beta version) developed by the EC Joint Research Centre aggregar' ted to $1 \mathrm{~km}$ resolution. Based on IRS-P6 LISS-III SPOT4 (HRVIR) and SPOTS HRG satelite data of 2006. Belarus, Moldova, Ukraine, Russian Federation, Forest share
estimated based on AVHRR NOAA satelite data of 1996-1998. Statistical data: National forest country statistics 2011

References:

Kempeneers, P., Sedano, F., Seebach. L., Strobl, P.. spatial resolution, J. 2011: Data fusion of differen to forest type mapping, IEEE Transactions on Geoscience and Remote Sensing, in print.

Päivinen, R., Lehikoinen, M., Schuck, A., Häme, T., Vaătainen, S., Kennedy, P., \& Folving, S., 200 Statistics. EFI Research Report 14. European Forest Institute, Joint Research Centre - European

Commission, EUR T991TEN. $101 \mathrm{p}$.

Schuck, A., Van Brusselen, J., Paivinen, R., Häme, T., Kennedy, P. and Folving, S. 2002. Compilation of a calibrated European forest map derived from
NOAA-AVHRR data. European Forest Institute. EFI Internal Report 13, 44p. plus Annexes: Contact: efisec@efinet

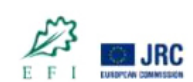

Only a limited number of recent studies address AFM under climate uncertainty (Yousefpour et al. 2012, 2013, Pukkala and Kellomäki 2012, Schou et al. 2012, 2015, Garcia-Gonzalo et al. 2014, Petr et al. 2014, Ray et al 2015). Several of these studies rely on the analysis of climate change, its impact on forest ecosystems, and the relation to management actions. However, there is an overwhelming reliance on ex ante simulation analyses to evaluate decision alternatives that are constructed in ways that do not fully embrace the problem. One key element that is often ignored is that as the future unfolds, more will be learned about the actual development of climate and its impacts. This has to be accounted for in the set of possible developments and decision alternatives considered, and doing so will allow simulation of the decision makers' potential to update their beliefs. For example, genetic diversity is a key element in the adaptive potential of forests. However, little information is currently available to measure and monitor adaptive genetic diversity or the suitability of provenance to future climates. That knowledge is likely to be available in the future so that this element can be added to AFM. Thus, forest scientists face the complex challenge of developing a meaningful and comprehensive understanding of AFM under climate change that is open to future insights and learning.

\section{METHODS}

We suggest a systematic framework to address the challenge of a forward-looking AFM strategy by decomposing it into three components: (1) expert and layman knowledge and the updating of beliefs; (2) a wide-ranging set of alternative management options; and (3) approaches to decision-making analysis and simulation that account for all the challenges reviewed above.

As we fold out the focus and considerations relevant for the three components, we illustrate how they may be approached using experiences from a number of case studies (Schou et al. 2012, Hengeveld et al. 2015, Palma et al. 2015, Ray et al. 2015, Schelhaas et al. 2015, Zell and Hanewinkel 2015; Trasobares, Thorsen, Jacobsen, et al., unpublished manuscript). Case studies from different bioclimatic regions were selected to reflect the diversity of European forests (see Fig. 1). They feature commonalities such as a focus on timber production and assessment of the impact of climate change on growth and competition, but different management goals were important in each case, e.g., risk management concerns such as forest fires; protection from natural hazards; optimization of biomass production; recreation; or nature conservation. 
Fig. 2. Three pillars of the suggested framework for addressing adaptive forest management (AFM) under climate change uncertainty. RCPs are four greenhouse gas concentration (not emissions) trajectories adopted by the IPCC (2014) for its fifth Assessment Report.

\section{Three Pillars of AFM}

\section{Knowledge}

- Identification of

uncertainty, e.g., based on

the number and spread of

RCP trajectories

- impacts of climate change

on forest ecosystems

- Identification of climate

change perception among

decision makers

- Ways to update

perceptions/beliefs

- Merging knowledge

through evidence fusion or

network building

\section{Options}

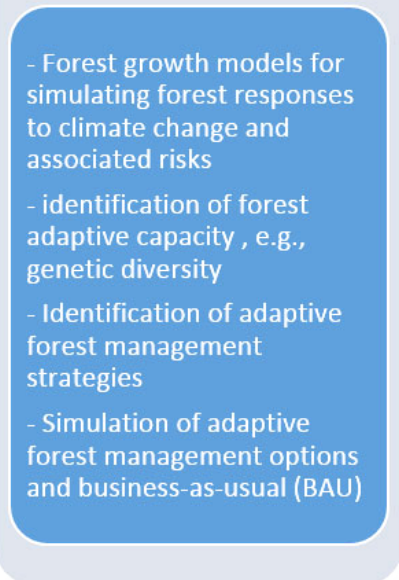

\section{Decisions}

- Evaluation of alternative

decision options, including

BAU and incorporating

multiple goals and

constraints of decision

makers into the process

- Optimization allowing for

updating and multifaceted

information building and

analyzing - trade-offs among

goals and optimization

outcomes

- Decision analysis and

adaptation priorities
Based on the lessons learned from these case studies, we identify the most suitable approaches to deal with climate change uncertainty and other associated risks, e.g., wildfires, to satisfy management objectives, ecological conditions, economic interests, and societal demands. We show the added benefit of relying on several rather than one single approach to deal with case-specific decision problems, e.g., adaptation to forest disturbances, maximizing biomass production, and socialecological sustainability of forest resources. We start by outlining the framework and then go into the details of each of the three components as pillars of the framework (Fig. 2). Moreover, we show how lessons from the pillars can be synthesized to provide additional insights and use these to derive research challenges for AFM.

\section{RESULTS: A FRAMEWORK FOR MODELING AFM UNDER CLIMATE CHANGE UNCERTAINTY}

Pillar 1: Accounting for expert and layman knowledge

The framework for the evaluation of forest management adaptation to climate change requires the following: (1) available expert knowledge on climate change projections, impacts of climate change on forest ecosystems, and associated uncertainties, (2) knowledge of decision makers' perceptions of the phenomenon, their behavior in handling the associated impacts and risks, and (3) knowledge of the way evidence is brought together by decision makers to form their beliefs about possible futures.
Knowledge and information about climate change and its impacts Climate change is likely to exert considerable impacts on forest ecosystems (Bonan 2008, IPCC 2014, Hickler et al. 2015). However, the future changes in climate and their impacts on forest ecosystems will always remain difficult to project with accuracy because there are no historical parallels to learn from, and because they depend on future emissions of greenhouse gasses (Allen et al. 2000, IPCC 2014). The response of forest ecosystems to climate change, their regional variation but also the sensitivity of the climate system to the fundamental anthropogenic forces, i.e. emission pathways, are uncertain. Typically, a chain of computer models is used to assess the impacts of climate change on forests. General circulation models (GCMs) are used to project global climate change. Regional climate models (RCMs) are used to spatially downscale GCM results. And dynamic forest models are used to project climate change impacts on forest ecosystem development (Lindner et al. 2014, Reyer et al. 2014). Each of these model chains is typically simulated for one or several scenarios that describe our expectation of how future greenhouse gas emissions might develop. These scenarios are usually described by archetypes in scenario documentations and abbreviated with labels such as A1, A2, B1, and B2 (Nakicenovic et al. 2000) prior to the fifth IPCC assessment report (IPCC 2013) and directly by radiative concentration pathways since then. Furthermore, it is important to be specific about what baseline is being considered. In the studies forming the basis for this synthesis paper, climate change projections from a range of GCMs and RCMs were 
downscaled to a $100 \mathrm{~m}$ spatial resolution using the change factor method (Diaz-Nieto and Wilby 2005, Anandhi et al. 2011). The downscaled data represent time series for given scenarios (A1FI, A1B, and B2) and given climate variables, e.g., daily or monthly temperature, precipitation (see Appendix 1), which were then used in all regional case studies.

Changes in climate and the increasing concentration of $\mathrm{CO}_{2}$ in the atmosphere affect forest growth and productivity (Hickler et al. 2015). For example, enhanced growth of Norway spruce (Picea abies) in Sweden and Finland (Kinnunen et al. 2013) and declining growth of common beech (Fagus sylvatica) in Flanders during the late 20th century (Kint et al. 2012) or increasing tree mortality (Bigler et al. 2006, Allen et al. 2010) have been attributed to a changing climate. Moreover, we face new patterns in the geographical distribution of forest disturbance agents and the frequency and severity of related disturbance regimes. During the past decades, there has been an increasing frequency of large-scale and intense damages to forests (Seidl et al. 2014), such as the Lothar storm in central Europe (Hanewinkel et al. 2011), forest fires in Spanish oak forests (San-Miguel-Ayanz et al. 2013), and windthrow in southern Sweden (Lindroth et al. 2009). Because forest models inherently include sources of uncertainty, using a broader array of models may improve outcomes (Lindner et al. 2014).

\section{Decision makers' perceptions of climate change}

Knowledge of the factors that trigger the human response to climate change is crucial for effective climate change communication and policy. Fifty percent of the forest area in Europe is privately owned (UNECE FAO 2011), rendering decisions by private forest owners an important determinant of the realized adaptive capacity of the European forest sector. Prevailing concepts of adaptation to climate change assume that local adaptations are mainly constrained by the broader economic-social-political structures (e.g., Smit and Wandel 2006), ignoring personal perceptions of climate change. Decision makers need to decide about their response in terms of AFM. Yet, personal factors such as the strength of belief in the local effects of climate change have been shown to correlate strongly with responses to climate change (Blennow and Persson 2009, Blennow et al. 2012) and there is a growing evidence supporting the conjecture that personal experience of climate change contributes to explaining the responses to climate change (e.g. Blennow et al. 2012). Observation of changes in forest growth, productivity, and damages may influence decision makers' perceptions about climate change and their need to decide on actions in relation to AFM (Yousefpour et al. 2012). In a study in three European regions that differ in economic, social, and political structures, Chamusca (Portugal), Black Forest (Germany), and Kronoberg (Sweden), the majority of respondents $(66.5 \%)$ believed in the effects of climate change on their forests as substantial (Blennow et al. 2012). Similarly, Yousefpour and Hanewinkel (2015) found that in southwestern Germany, $83 \%$ of the respondents $(n=262)$ perceived climate change as having anthropogenic origin, but most of them $(70 \%)$ did not believe the risk of climate change to be very high.

\section{Updating beliefs for use in decision making}

How uncertainty and observed impacts of climate change are reflected in forest management decisions depends on the way they are interpreted by different types of decision-making processes (Petr et al. 2015). Below, we describe four stylized types of decision-making processes that differ in how they (1) take into account uncertainty and new information on the state and development of the climate and (2) evaluate alternative management decisions: the "no-change," the "reactive," the "trend-adaptive," and the "forward-looking adaptive" decisionmaking types (Fig. 3). The climate to be realized is unknown in all types, but available information is interpreted and applied differently in their assessment of the future.

Fig. 3. An illustration of climate change expectations seen at time point "now," i.e., ENow(Climate) to the several decision points in the future. The colors illustrate the different expectations of decision-making types. Blue is the observed and unique change in the past. Red is the expectation under "nochange decision making," where past treatments are repeated as long as they appear to work. The black expectation refers to "reactive decision making," where decisions are changed based on the observed change in the past. Green refers to "trendadaptive decision making," where adaptation to the predicted trend occurs. Blue-grey shadows denote "forward-looking adaptive decision making," where a range of possible futures is expected and where the expectations get broader, i.e., more uncertain, as we go more distantly into the future.

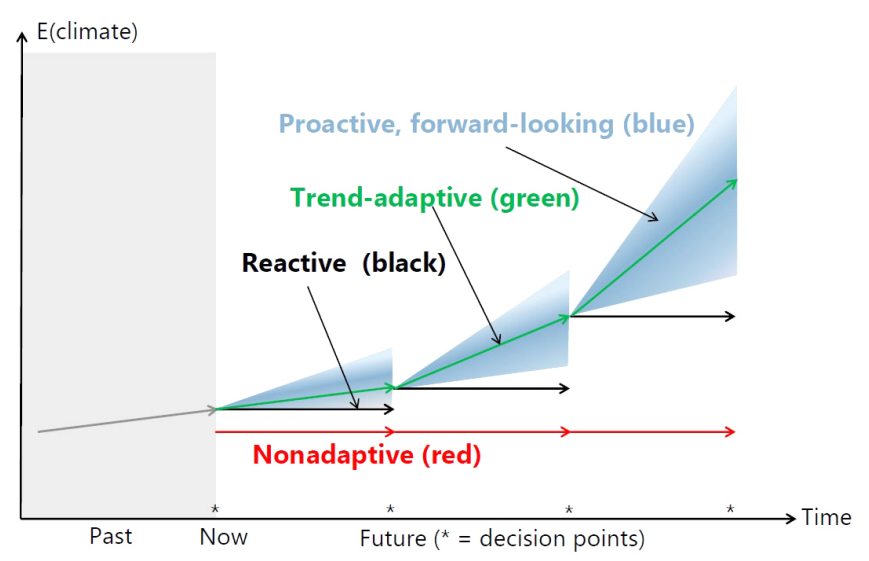

The no-change and reactive types of decision making base decisions at any point in time on available information about past and present climate states only. The decisions do not depend on expected and predicted future fluctuations, trends, or asymptotic behavior of the climate. They differ in whether beliefs are updated to the currently observed climate or not (the point "now" in Figure 3 ). No-change decision making assumes that past climate will persist, and any temporary variation is just considered trendless fluctuations, so the best guess of the future is the original starting point. The reactive decision making type notices the present state of climate (Hoogstra 2008), and the expectation is that it will prevail. Here current fluctuations play a large role. Therefore, adapting and reacting to already experienced climate change impacts is possible by changing business-as-usual (BAU) to a new set of reactive strategies that are adapted to current conditions.

Trend-adaptive decision making takes into account expert predictions of the most likely climate change scenarios and its 
impacts on forest, e.g., projection of future forest conditions under the most likely representative concentration pathway (RCP) scenario. The decisions also consider the presently observed climate and forest conditions, but are not based on the belief that the past repeats itself. Thus, they look forward and react to beliefs about the trends. However, when making a management decision, the uncertainty characterizing the situation is not fully taken into account, and the decision-making process is not designed to include learning. We return to this type of decision making in our discussion of simulation-optimization studies.

Finally, in forward-looking adaptive decision making the state of the climate and the forest, as well as recent and ongoing climate change are observed, but instead of formulating expectations in the form of a single trend or scenario, the uncertainty inherent in the predictions of climate change and particularly in the likely impacts is acknowledged. Therefore, a spectrum of outcomes is considered, and most importantly, a repeated evaluation process is used to make new projections in the future based on improved observations that have the ability to modify decisions at future points in time according to observed changes. Already when evaluating current decision alternatives, the possibility of future adjustments is taken into account. Thus, decision making is dynamic in this mode and fully adaptive; forward-looking decision makers redesign AFM strategies taking full advantage of the information available on climate change and from monitoring impacts on forests. We use this case to illustrate a way on how beliefs can be systematically updated.

\section{Example of using Bayesian updating of beliefs}

Bayesian updating approaches (Bayes and Price 1763) may serve as a mathematical model of how decision makers behave and process information. Studies in Veluwe and the Black Forest (Yousefpour et al. 2013, 2015) applied this approach using climate change scenarios (see Appendix 1) in combination with various representations of the behavior of forest decision makers. Results show how the divergence of climate change scenarios and the variation of observed climate, e.g., temperature or precipitation, or forest properties, e.g., forest growth and disturbances, may affect beliefs about the real future development of climate change scenario (Fig. 4). Beliefs were updated based on observations from the last 30 years, as the maximum effective memory time for inference, and giving more weight to recent observations.

Generally speaking, each decision is based on observed trends and fluctuations of particular stochastic variables, projections of these, current and new policies, and other sources of information. They all influence the resulting beliefs of the decision maker regarding the future state of nature. Because we are not always able to comprehensively describe and quantify uncertainty, it is useful to include the formation of beliefs in a model of decision making. Repeated, direct observations of climate variables have the advantage of providing reliable information on the variation and change of climate. In contrast, information on the development of forest variables is not a direct measure of climate change because forest variables are influenced by other factors, e.g. anthropogenic, and subject to large temporal lags. Forests are also likely to respond in a nonlinear way to weather phenomena, e.g., droughts. Thus, forest variables constitute a more complex, yet more integrative source of information. To address the complexity of using several sources of information for forming beliefs and making decisions,
Yousefpour et al. (2013) applied Dempster's rule (Dempster 1967, Bernetti et al. 2011) to combine multiple updated beliefs, each based on a different observed variable (Jøsang and Pope 2012). This rule takes into account all the available evidence and gives more weight to beliefs causing the least conflict among evidence as the source of uncertainty. For example, if all observations of climate and forest properties signal a harsh change in climate, scenarios specifying a harsh climate change will receive the highest belief mass. It emerged that the direct observation of the climate state was superior to observations of the forest state in updating beliefs toward the real climate change scenario. It also turned out that observing more than one variable, e.g., several climate variables, can also be beneficial.

Fig. 4. Updating beliefs about the real future development of climate change scenario, when Bayesian updating is based on the observation of different climate and forest variables drawn from 100,000 Monte Carlo samplings (source: Yousefpour et al. 2013). Red, green, and blue lines indicate high, moderate, and low change in climate, respectively (top left). Dotted lines illustrate the variation of climate variables (top left), and hyphenated lines show the variation of forest variables (top right) over time. Dashed lines show the development of beliefs on climate change scenarios based on observing climate (bottom left) or forest variables (bottom right).

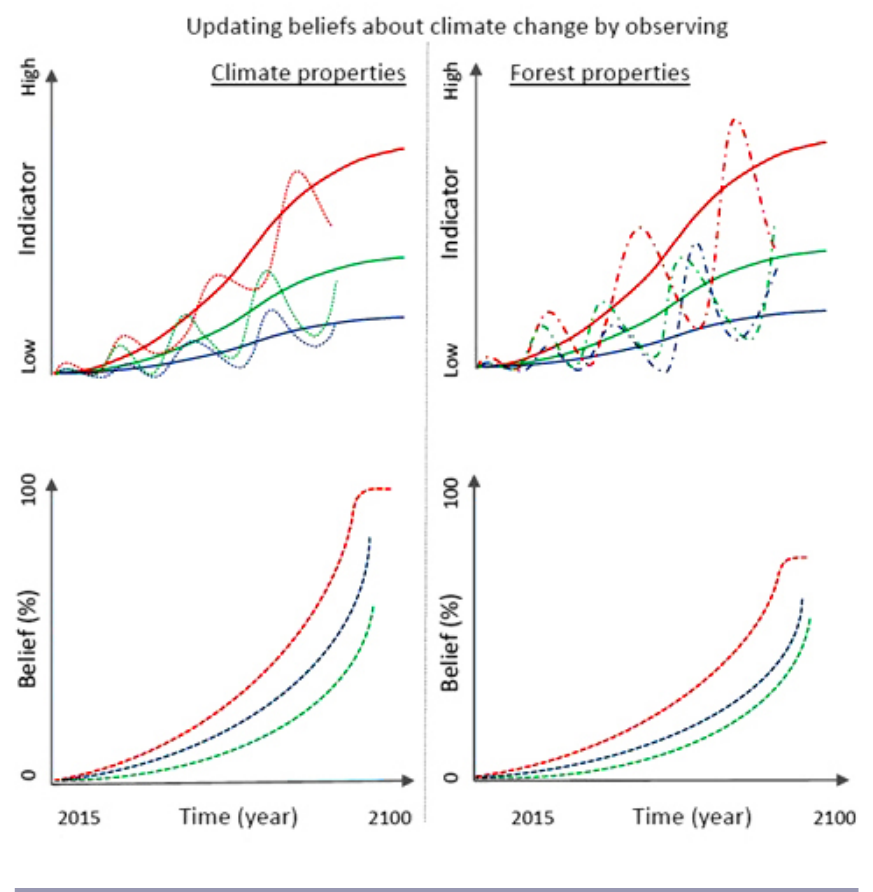

Summary of the most important lessons of Pillar 1: Knowledge

- Decision makers are assumed to shape their perception about climate change based on direct observation of climate properties and impacts on forest ecosystems.

- Decision-making processes may vary in the way and the amount of the climate change knowledge they integrate in making decisions about AFM strategies. 
- We assume that the greater the short-term variation in climate variables around any deterministic trend of change, the longer it will take for agents to recognize a realized trend.

- The narrower the span of climate change projections that are being considered as possible futures, the harder it is to assign observations to any given projection and, consequently, the longer it will take to determine the correct one and the greater the risk is to not include the true development in the set of considered scenarios.

- If beliefs about climate development are based on limited observation and information sources, the true climate development can be recognized faster with more direct observation of climate variables and projected impacts can be accounted for.

- Considering forest variables indirectly related to climate change and subject to lagged climate impacts, effects of factors not related to climate and infrequent observation leads to longer time spans required to determine the true climate development.

- Combining different sources of information in models is useful and approximates the way people make their beliefs about climate change.

Pillar 2: Generating management alternatives

Climate change impacts on forests and their reaction to management should be analyzed to gain knowledge that may contribute to increase feasibility of achieving desired forest structure and provision of ecosystem goods and services under uncertainty of future state predictions. Interventions for active adaptive management of forests include a large variety of alternatives, including changes in species composition by converting monocultures to mixed forests; changes in forest structure, e.g., conversion from even-aged to uneven-aged or coppice to high forest; and forest risk reduction by measures such as fuel treatments, intensified thinning, or the reduction of rotation time (Kolström et al. 2011).

\section{Forest growth under climate change}

Climate-sensitive forest growth modeling tools can be used to simulate forest development subject to climate change scenarios and management options. The reliability of these simulations is higher for short-term predictions and more models are succeeding to link forest productivity and disturbances in the long term (e.g., Reyer et al. 2017). The need for such models is recognized, but the development is still in its infancy (Reyer et al. 2013). Appendix 2 provides an exhaustive list and detailed information about the applied forest growth models and their integrated features of risks and options for adaptation. Later decisions (cf. Pillar 3) can then be carefully analyzed regarding management options and timing of adaptation. If the changes implied by an adaptation alternative are fundamental and irreversible to forest structure and functioning such as a change in species composition, it may be preferable to wait and decide about required adjustments at a later time. Such a behavior can be captured with so-called "real options approaches" to decision making (Thorsen 1999a, Jacobsen and Thorsen 2003, Brunette et al. 2014). Including an assessment of genetic and functional diversity among and within species in the decision process could help in avoiding such irreversible effects. Information on the performance of provenances in different climates and the genetic background of functional traits becomes available but is still largely uncertain for future climates.

\section{Long-term genetic adaptation}

The long-term adaptation potential is, in the genetic sense, the base of any adaptation of forest ecosystems to changing environmental conditions and is likely to be strongly affected by climate change, land use change, and by the adaptive forest management actions themselves. In the face of climate change is the concern that environmental changes are projected to occur at such a rate that trees cannot adapt fast enough (Davis and Shaw 2001). Tree species have been exposed during their evolutionary history to long-term environmental change, and have shown capability to respond and adapt to these changes. Historical evidence suggests that they have evolutionary potential to cope with considerable climatic changes (Hamrick 2004). Historical evidence suggests that they have evolutionary potential to cope with considerable climatic changes. Rapid evolution in situ might be possible in populations that have existing genetic variation in fitness-related traits, that experience high levels of gene flow from better-adapted populations (Kremer et al. 2012), or that gain better-adapted genotypes through mutation. In almost any tree species for which provenance tests have been conducted significant variation between populations has been observed for fitness-related traits. For example, bud burst shows a clear latitudinal variation in all conifers, with northern provenances flushing earlier and setting bud earlier than southern populations (Wright 1976), whereas oak species exhibit the opposite cline (Vitasse et al. 2009). Genetic diversity is also very high within tree populations (Alberto et al. 2011) and may improve the long-term potential of forests to adapt to climate change. Intra-population genetic variability can thus be seen as a natural capital upon which future adaptation will rely. However, some traits such as resistance to drought-induced cavitation have extremely low genetic variability (Lamy et al. 2011), suggesting that the adaptive capacity of tree populations to increased drought will be limited (Lamy et al. 2014). This situation may also apply where changes might simply be too rapid for some species to evolve. Currently, genetic processes to simulate adaptation in process-based individual tree models are being implemented and indicate that adaptive responses are relevant even for trees (Kramer et al. 2015)

Genetic diversity (between and within populations) can be supported by the use of natural regeneration techniques. The regeneration phase is susceptible to changes in climate (Spittlehouse and Stewart 2003) because young seedlings and plants are particularly sensitive to extreme climatic events (Oliet et al. 2002). Regeneration therefore gives opportunities to adapt the selection of tree species or genotypes to a changed climate. A highly recommended option to secure the adaptive response of established regeneration is to raise the level of genetic diversity within the seedling population, either by natural or artificial means by selecting provenances from a region with current climate well matched to the planting site's predicted climate of the future (Broadmeadow et al. 2005, Lamy et al. 2014). Forest growth models including the genetic background of individual trees are available and increasingly applied for climate change assessment (Kramer et al. 2008, 2010, 2015). Such information, and its uncertainly, should be considered in the forward-looking adaptive decisions. 


\section{Adaptive strategies}

Adaptation may be considered at the stand level (e.g. Ferreira et al. 2012), but it is also possible to integrate spatial information in the process of AFM, especially when it concerns an entire forest enterprise or a whole landscape. Spatially explicit adaptation is fundamental if the forest management problem is highly sensitive to geographical characteristics, e.g., elevation, slope, aspect, or soil quality, and to effects of neighboring stands, e.g., the spread of fire and insect disturbance. Diversity of management strategies at the landscape level, e.g., using different species mixtures in neighboring stands, is also an adaptation option that minimizes risks (Kolström et al. 2011).

In Appendix 3, adaptive management options are reviewed for a range of case studies where an active adaptation of forest resource management (trend-adaptive and forward-looking management types) were sought to respond to foreseen and unforeseen environmental conditions and changes. The number of alternatives to BAU is often large and asks for ranking and eventually optimizing the process. Spatial and temporal planning and decisions on the intensity of management alternatives take into consideration a range of options, such as species mixture, stand structure, thinning regime, and rotation time. Complex alternatives, e.g., maintaining a desirable forest structure, may be considered as an adaptive strategy, e.g., maintaining mixed broadleaved forests in Romania (Walentowski et al. 2013, Bouriaud et al. 2015). BAU typically refers to the stand scale, but adaptive management options may encompass landscape-level structures, e.g. the degree of fragmentation, to address impacts of climate change on habitats, or the spread of wildfires (González-Olabarriaa and Pukkala 2011, Ferreira et al. 2015). We acknowledge that even more substantial adaptation measures than those recommended in Appendix 3, e.g., introducing exotic resistance species, may become inevitable in the face of severe and more uncertain future environmental changes.

\section{Simulation of adaptation strategies}

To assess the outcomes of alternative strategies under climate change we need forest growth models that ideally (1) can provide estimates of timber production and other goods and services as a function of stand-level characteristics, (2) are sensitive to environmental changes, particularly climate but also variables such as $\mathrm{CO}_{2}$ and nitrogen, (3) are able to link stand-level output to provide landscape-level results, and (4) are efficient enough to provide state-of-the-art projections of key state variables and flows at low computational costs, hence allowing for the evaluation of numerous decision alternatives (Yousefpour et al. 2012). Examples of applications of such models are adapting the individual tree model SUBER (Palma et al. 2015) and using optimization techniques to suggest adaptive strategies for cork oak (Quercus suber L.) in Chamusca, Portugal; using the empirical model BWinPro to identify the most disturbance-adaptive management strategies for increasing forest resistance to windthrow in southwest Germany (Zell and Hanewinkel 2015); or applying a combination of different forest growth, risk, and wood assortment models (Ray et al. 2015) to comprehensively investigate the suitability of adaptive strategies for the provisioning of ecosystem goods and services in Wales, UK. Moreover, the European forest information scenario model EFISCEN was used to simulate the effects of applying a reduced rotation time and replanting more adapted species in different
European regions (Schelhaas et al. 2015). The models are still far from being perfect and simulation of some complex forest processes are in their infancy.

An important lesson of Pillar 2 is the importance of evaluating the performance of AFM alternatives against the baseline BAU. No studies evaluating alternative forest management under climate change can validly do so without a credible benchmark (Yousefpour et al. 2014). Although BAU may be well adapted to the climate of the recent past, there is no guarantee that it will be a suitable, let alone an optimal option under new, uncertain environmental conditions. Thus, to form a sound basis for decision making, the set of adaptive strategies must be sufficiently large that it encompasses the goals and constraints set by the decision makers of individual case studies (Yousefpour et al. 2014). It is equally important that the set of adaptive forest management options are generated in a way that takes into account a large potential variation of future climate change. Narrow sets of alternative strategies relying on narrow (perhaps implicit) assumptions about possible climate change are likely to miss out on relevant decision options in low-probability, highimpact scenarios, and will therefore not support sound decision support across the potential state space.

Summary of the most important lessons of Pillar 2: Adaptation options

- AFM analysis should rely on a transparent and systematic set of alternative decision options, including a credible business-as-usual management scenario.

- Alternative options should be generated in ways that cover the range of possible goals for the stakeholders. Too narrow a focus implies a risk of suboptimal advice.

- Alternative management options should take into account a wide range of potential climate change developments, even if they may be dominated by outcomes that are close to current climate.

- Genetic information on performance of provenances in different climates, the genetic background of functional traits, and the level of necessary genetic diversity of forests are already, or will become, available in the near future. Such information on, among, and within species' functional and genetic diversity should be used in AFM to avoid unnecessary drastic decisions such as changes in species composition of forests.

- The selection of adaptive management options must take into account specific ecological and socioeconomic conditions, potentials, and needs of the forest regions to ensure sustainability of forests and provisioning of demanded goods and services.

- Learning from past and current adaptive activities and management interventions of successful strategies should be promoted to expand the scope and quality of decisions.

\section{Pillar 3: Decisions on adaptive management options}

This pillar integrates all the knowledge and outcomes from the first two pillars to identify the most suitable AFM strategy. A simple mathematical representation of the framework could be Equation (1), where the expected value $(E)$ at time ( $t$ ) across a set of options $(j)$ for action $(A c t)$ can be maximized (max.) using 
beliefs $(\mathrm{Bel})$ related to a number $(n=1 \ldots N)$ of climate change scenarios and values of the actions under each scenario ( $\mathrm{Val})$ :

$$
\underset{j}{\max . E_{t}}=\sum_{n=1}^{N} B e l_{n t} V a l_{n t}\left(A c t_{j t}\right)
$$

\section{Evaluation of AFM strategies and multiple objectives}

The first step is to evaluate the alternative strategies, starting by setting the goal and objectives of the decision maker. In forestry, goals are often characterized by multiple elements (cf. Appendix 4), e.g., maximizing economic outcomes (net present value), biomass and timber production, and minimizing risks and hazards.

Once goals are defined, the challenge is to collect and integrate the necessary information as it becomes available (Prato 2009, Probert et al. 2011), thereby allowing for decisions on adaptive management. It is evident from Pillars 1 and 2 that adaptive forest management in the face of climate change uncertainty can be understood as a continuous or at least repeated adjustment to the development of major exogenous factors that have great influence on the (economic or social) outcome of the decisions, and hence on performance relative to objectives. We drew upon a diverse set of case studies that apply different techniques and regard a set of objectives and constraints (cf. Appendix 4) to identify some kind of resolutions for complex and wicked forest management problems under climate change.

Optimization techniques and trade-offs among objectives Optimization techniques can be used to resolve large and complex decision-making problems. For example, in a case study in Switzerland, the economic performance, i.e., land expectation value (LEV) of beech stands in Alpine areas in Switzerland were optimized by changing management for four different climate developments, current climate, and three regional circulation model realizations of the IPPC AR4 A1b emission scenarios (see details in Appendix 1; Trasobares, Thorsen, Jacobsen, et al., unpublished manuscript). The decision variables were the stand age at and intensity of the first and second thinning as well as the age at the first regeneration cut. In this study, the LEV response surface of the optimization problem is rather flat meaning that the cost of making wrong decisions about AFM is quite small. To manage forest risk, a stochastic dynamic programming (SDP) approach was applied to select the optimal sequence of management activities, including fuel treatment and timber harvest, for a fire prone stand assessing trade-offs among multiple objectives and estimating opportunity costs of nonoptimal prescriptions in a risk context. The advantage of stochastic dynamic programming is that at any point in time within the planning period it provides insight about what path to follow for designing adaptive policies without a fixed calendar of operations that needs to be defined a priori. SDP has been recognized as a very powerful tool for optimizing management scheduling of Maritime pine (Pinus pinaster Ait.) stands (Ferreira et al. 2012) and short-rotation coppice systems (Ferreira et al. 2012) under fire risk, both in Portugal. Ferreira et al. (2016) developed a dynamic programming approach to define stand-level adaptive management strategies in a context of climate change.
The development of landscape-level adaptive management strategies may be facilitated by other quantitative techniques, e.g., integer and mixed integer spatially explicit models, stochastic optimization models, and heuristic approaches (Ferreira et al. 2015, Garcia-Gonzalo et al. 2016). For example, Ferreira et al. (2015) produced an innovative mixed integer programming approach that combines the use of a growth and yield model, a shrub biomass accumulation model, and wildfire occurrence and postfire mortality models. They used this approach to assess the impact of alternative spatial arrangements of landscape elements on resistance of a forested landscape to risk, e.g., fire. Another promising approach is the active use of Bayesian updating of beliefs regarding possible future developments, possibly also including the use of Dempster's rule of evidence combination or similar tools that enables continuous belief updating in simulations and evaluation of alternatives. Although this approach has been applied successfully in several studies, we believe that there is potential to expand this by new approaches, e.g., in species distribution models (Hanewinkel et al. 2013) that can include assessments of a larger scale that covers alternative spatial arrangements of landscape elements.

Reviewing these studies provides a number of lessons on decision making. The process of decision analysis in most cases involves (i) identifying the adaptive decisions under a range of possible scenarios, (ii) finding the best timing (in terms of time or state of the system) of switching from BAU to an adaptive decision alternative or from one adaptive to another adaptive alternative, and (iii) updating information and beliefs repeatedly and revisiting adaptive decisions again if necessary. Some of the recommendations from AFM simulation studies that were found to be particularly informative included the following:

- a set of silvicultural interventions, e.g., conversion of monocultures to mixed forests (Norway spruce in the Black Forest converted to beech-spruce mixtures; Temperli et al. 2012, Yousefpour et al. 2013);

- introduction of admixed tree species (Veluwe; Yousefpour et al. 2015);

- intensified harvesting to reduce standing stock (Spain; González-Olabarria and Pukkala 2011);

- admixing conifers with broadleaves (Denmark; Schou et al. 2015);

- establishing plantations with several species (Wales; Ray et al. 2015) or prolonging rotation period (Portugal; Ferreira et al. 2012, Garcia-Gonzalo et al. 2014, Palma et al. 2015).

Decision analysis and adaptation priorities

A critical feature often overlooked in decision analysis (perhaps because it adds "noninteresting" inertia to the results) is the role that the current state of a forest can have for the optimal path of adaptive management actions over time (cf. Temperli et al. 2013). Although in some cases, the adaptive alternatives could be optimally implemented now, it is much more common that the optimal decision involves postponing such changes in order to benefit from the current productivity of maturing forests, which may be vulnerable to climate change at a later point in time, but not sufficiently so currently. An example of this is the study of 
adaptation alternatives for forest stands in the Veluwe (Yousefpour et al. 2015) and in Britain (Petr et al. 2014), where the productivity of the present forest remains high for a long time, before extreme disturbance events are realized (cf. also Elkin et al. 2013). Current management is therefore superior for the nearterm future. However, this depends strongly on stand age, and sometimes it was found that the expected value of postponing harvest is negatively correlated with stand age (e.g., Schou et al. 2015).

It may be more important to identify suitable adaptive strategies for low productivity sites than for often less sensitive, highproductivity sites if the goal is to maintain production. For example, beech stands in Switzerland are more sensitive to climate change with an expected very high loss in economic productivity at poor beech sites (income loss and crucial investments required for ensuring resilience) compared to highly productive beech sites losing a very low percentage of their economic output (Trasobares, Thorsen, Jacobsen, et al., unpublished manuscript). Compared to the worst decision (nonadaptive management), the largest possible gain (with an adaptive decision made with perfect information about climate change and its impacts) could be up to $122 \%(23 \%-122 \%$ of land expectation value; see Yousefpour et al. 2014), whereas for the worst strategy the overall loss was $34 \%$ compared to the optimal strategy in terms of total expectation value (Schou et al. 2012). Although relative changes may be large for poor sites, absolute loss may be smaller because of their low productivity. However, particularly in situations where such forests, besides biomass production, serve other purposes, e.g., as protection forests, early adaptive measures may be socially optimal.

\section{Summary of the most important lessons of Pillar 3: Decisions}

- Decisions on adaptation vary across European forest landscapes, partly because the severity and importance of foreseen impacts of climate change differ among regions and partly because ecological as well as socioeconomic conditions vary.

- Decision-making tools are useful in exploring a large decision space subject to multiple goals and constraints and finding the most suitable adaptation strategy for forest resource management under climate change.

- Knowledge-based decision analysis is essential for the management of forest enterprises incorporating subjective beliefs of decision makers about climate change.

- Decisions on whether to adapt immediately or to postpone adaptation in the hope of receiving more information in the future, should be made carefully using a real options approach. This guarantees the flexibility of changing decisions in the future and allows analyzing the trade-offs between high costs of irreversible decisions and damage caused as a result of delayed adaptation.

- Re-evaluation of decision alternatives at later stages is recommended in order to take into account revised beliefs about climate change and its impacts and lessons learned from applying certain adaptive management options.

- Adaptation is most critical on poor sites in forest ecosystems that are highly vulnerable to climate change and its consequences and in areas where regulating and protecting forest ecosystem services are of great importance.

\section{DISCUSSION}

We outline a systematic framework for developing an understanding of AFM under climate change, which involves three main components (pillars) to be addressed in research: (i) information and knowledge integration and belief formation, (ii) tools for generating and assessing alternative management options, and (iii) approaches to decision analysis. Here we will discuss the experience of the use of the framework, its applicability and adoption for finding AFM strategies, and perspectives for further developments.

\section{Main lessons learned from the framework}

Regarding knowledge, we emphasize the importance of the past as well as the most recent knowledge on climate change developments and their likely impacts, when undertaking decision analysis for use in a normative setting, e.g., supporting forest policy and forest owners in their decision making. Not all decision makers perceive climate change issues in the same way (Petr et al. 2015), and decision makers form different subjective beliefs as surveys of forest owners' perceptions have shown (Blennow and Persson 2009, Blennow et al. 2012, 2016). Hence we turn to a positivist approach and recommend our framework for analysis of ongoing adaptation behavior and heterogeneity across different decision makers (Steel et al. 2004).

Regarding options identified as AFM alternatives, we stress several issues. First and foremost, we stress the importance of a structured and systematic generation of a wide range of alternative management alternatives, allowing for the pursuit of objectives under a wide range of possible climate change developments, and for reliable state dependent performance assessments relative to a BAU strategy. Second and for the simulation of alternative strategies, it is important that climate variables are explicit in forest growth models, so that climate sensitive simulations of future growth and responses to management interventions can be made based on process understanding (e.g. photosynthesis), rather than empirical experiences only. This is needed both at stand and landscape levels because stands may not react independently and, further, the landscape structure may determine climate change impacts on the landscape-scale supply of ecosystem services. Moreover, the modeling outcomes are more reliable for relatively short-term planning and before uncertainty increasingly propagates. For long-term planning, however, formal scenario planning might be more appropriate (Thompson et al. 2012).

Regarding decisions, we emphasize that the chosen techniques should be adjusted and developed to allow for incorporation of a wide knowledge base, multiple goals, and management system diversity. For example, various optimization techniques may be used in combination with Bayesian belief updating to maximize predefined objective functions in a multistage framework. In real world applications, this can be realized by the iteration of the decision-making process, i.e., by regularly updating beliefs and objectives integrating the most recent knowledge. The added value of applying a forward-looking adaptive decision-making procedure is that alternative decisions are identified in advance and that regular monitoring can then assess if a change in the 
preference between the alternatives is advisable. When making policy decisions affecting management at a landscape level, it is important to acknowledge not only what is good climate adaptation management but also the different levels of knowledge and possibly conflicting goals of decision makers and other stakeholders. This calls for the application of a combination of multistage and multiple-criteria approaches (e.g., Borges et al. 2014) that facilitate both the analysis of trade-offs between goals and the negotiation between decision makers.

\section{Implications for practice derived from using the framework}

AFM alternatives are greatly diverse and local. They can (i) be determined as a set of silvicultural interventions to be applied over an adaptation period, (ii) take into account different objectives and constraints in the decision-making process, (iii) change forest structural properties toward robust and adapted ecosystems. Increasing the frequency of thinning interventions (Jacobsen and Thorsen 2003) and intensifying harvesting in vulnerable stands to the likely risks of windbreak (Zell and Hanewinkel 2015) and fire under climate change (GonzálezOlabarria and Pukkala 2011) and admixing conifers with broadleaves and diversifying tree species (Yousefpour and Hanewinkel 2015, Temperli et al. 2012) are just examples of the most recommended AFM options. Moreover, it is common in commercial forestry practices to impose a fundamental modification to the forest structure such as change in the major tree species (see, e.g., Ray et al. 2015), prolonging rotation age (Plantinga 1998), or doing nothing before sufficient information about the climate and forest development is gained to make optimal decisions (Thorsen 1999b, Yousefpour et al. 2013).

Climate change adaptation management is not only fundamental for commercial forest management but also to managing noncommercial forests and safeguarding their sustainability. A recent analysis of mega-fires in the Mediterranean by SanMiguel-Ayanz et al. (2013) supports our recommendations for forward-looking active adaptation by promoting fire-prevention oriented forest management and proposes that increased prevention is preferred over the increase in fire-fighting to reduce damages caused by mega-fires. Similarly, AFM strategies would enhance the biomass production of forests in the Carpathian region by implementing more intense and earlier harvesting and thinning and by replacing the old declining forests with young and highly productive forest ecosystems (Bouriaud et al. 2015).

Any practical decision making situation will always involve the options (a) to adapt now based on the imperfect information about the climate change and impacts on forest asset that is available or (b) to wait and update the knowledge over time to a level that for example justifies the costs of applying AFM (Yousefpour et al. 2012, 2013, 2014, Schou et al. 2015). However, taking AFM alternatives into consideration does not guarantee the ex post superiority of AFM decisions (based on the decision criteria) over BAU or conservation options. The ex post results will always depend on the actual development taking place. If there is no or only a small change in climate (Yousefpour et al. 2013, 2014) or if there is a small performance difference between BAU and AFM strategies (Fitzgerald and Lindner 2013), the BAU may very well be preferred with the wisdom of hindsight. Similarly, if climate change impacts appear more dramatic than assumed in the chosen AFM strategy, other alternatives would, in hindsight, have been better. However, the value of AFM is usually higher ex ante if a considerable change in climate is expected that is large enough to justify adaptation costs (Yousefpour et al. 2014, Schou et al. 2015) and the relative loss in forest productivity sometimes implied by AFM strategies (González-Olabarria and Pukkala 2011; Trasobares, Thorsen, Jacobsen, et al., unpublished manuscript). Moreover, multistage approaches may help to either decompose adaptive management strategies into short- and long-term prescriptions (Hoganson and Rose 1987) or to propose short-term adaptive policies that are consistent with observed evidence from monitoring compared to the estimated scenario outcomes (Ferreira et al. 2012), thus increasing the potential for higher values for AFM. The proposed forward-looking decision-making type provides an opportunity to make use of monitoring results and update management decisions at multiple stages over time.

\section{Further research avenues}

An improved understanding and models of the processes that govern forest development under climate change and varying management interventions is at the core of the presented framework and the basis upon which decisions are formed. An accurate representation of the current state of the forest is a prerequisite to gaining insights regarding future forest development. With forest succession modeling increasingly integrating the spatial contingencies of forest management, disturbances and dispersal processes, tree-level representations of current forests at the scale of entire mountain slopes, valleys and catchments or even landscapes is pivotal (Seidl et al. 2011, 2014, Zurbriggen et al. 2014). Recent advances in remote sensing and particular LIDAR interpretation are especially promising tools for the wall-to-wall mapping of tree species, densities and sizes of, e.g., biomass, density at breast height, and volume (Hyyppä et al. 2012). A further key element of process understanding that needs further attention is tree mortality. Although many empirical and probabilistic models of tree mortality have been developed so far (e.g., Wunder et al. 2008, Allen et al. 2010, Hülsmann et al. 2016, Vanoni et al. 2016), the underlying processes and particularly their interactions are still poorly understood (Bigler et al. 2006, McDowell et al. 2011) making the integration of tree mortality in dynamic forest models challenging (Manusch et al. 2012). In particular the implementation of disturbance-induced mortality and interactions and feedbacks among different disturbance agents, climate, vegetation, and forest management requires further process and understanding (Seidl et al. 2011, 2013). Large uncertainties also complicate assessments of the effects of increased ambient $\mathrm{CO}_{2}$ concentrations on tree growth, water-use efficiency, and other plant physiological processes (Bader et al. 2013, Reyer et al. 2014, Klein et al. 2016). An additional key element of forest dynamics that has received comparatively little attention is the interaction between forest management and forest genetic diversity and climate change impacts. Genetic aspects are rarely taken into account in the development and evaluation of adaptive management strategies, despite that genetic variation is an important component of such a system (Finkeldey and Ziehe 2004), and that it is likely to be influenced by the adaptive forest management actions selected. This will in turn affect the long-term options for adaptive forest management. We believe that adaptation via genetic diversity can be integrated in the suggested framework. To our knowledge the only study dealing with decision making and genetic diversity under climate change is Bosselmann et al. (2008), who, based on 
a clonal trial on Norway spruce, evaluate the value of genetic diversity in the face of climate change by the use of a real option approach. Therefore, we propose to enhance genetic diversity as an adaptive strategy for a medium to long time horizon. We suggest the use of such approaches in conjunction with Bayesian updating in relation to practical forest management, as a way to further examine novel approaches and to diversify adaptation measures under climate change.

The presented framework may carefully be combined with other decision-making procedures like quasi-option and heuristic methods to solve a wide range of forest decision-making problems. Restrictions and assumptions in the modeling of adaptive management can be relaxed as computation techniques develop and allow for the exploration of problems of larger dimensions and correspondingly greater decision spaces. However, another emerging research priority is the further improvement and expansion of our approach to understand and model decision-making process integrating the role of decision makers. Acquiring more empirical data on the behavioral aspects of stakeholders and decision makers and integration of actual perceptions of decision makers not only on the uncertain scenarios but also on the capacity of proposed alternative management strategies for successful adaptation (Blennow et al. 2012) would improve policy analysis on AFM to a great extent.

\section{CONCLUSION}

Because climate change is a dynamic and complex phenomenon we need to (i) monitor its physical state, i.e., most indicative properties, to recognize the actual climate development, (ii) consider the impacts of this development on biological systems, and (iii) integrate knowledge and beliefs of decision makers into dynamic models of decision-making processes. Therefore, policies targeting the application of a single adaptive management strategy to a greater area, e.g., a region or an entire country, may be suboptimal for some forest owners and/or properties. This underscores that structured and transparent generation of decision alternatives should span a sufficiently large decision space. AFM strategies should at least aim at maintaining current forest ecosystem goods and services provision and at providing an opportunity to implement prevention strategies against increasing damages to forest caused by factors with high regional impact, i.e., disturbances such as forest fire, windthrow, and pathogen calamities. Forest resilience to climate change will be enhanced through fostering diversity at different levels, e.g., AFM and genetic adaptation. This starts with better consideration of genetic diversity in AFM strategies, but applies also to the combination of different AFM strategies at the landscape scale and the consideration of alternative decision-making approaches.

Responses to this article can be read online at: http://www.ecologyandsociety.org/issues/responses. php/9614

\section{Acknowledgments:}

This work was supported by the Seventh Framework Program of the EC Grant Agreement No. 226544. We thank the MINECO "Ramón y Cajal" ( Ref. RYC-2013-14262) for funding the research contract of JGG. KK was funded by the project Resilient Forests (KB-29-009-003) of the Dutch Ministry of Economic Affairs. BJT and JBJ acknowledge support from the Danish National Research Foundation (DNRF Grant No 96). This research has received also funding from the European Union's $H 2020$ research and innovation program under the Marie Sklodowska-Curie grant agreement No. 691149 (SuFoRun).

\section{LITERATURE CITED}

Alberto, F., L. Bouffier, J.-M. Louvet, J.-B. Lamy, S. Delzon, and A. Kremer. 2011. Adaptive responses for seed and leaf phenology in natural populations of sessile oak along an altitudinal gradient. Journal of Evolutionary Biology 24:1442-1454. http://dx.doi. org/10.1111/j.1420-9101.2011.02277.x

Allen, C. D., A. K. Macalady, H. Chenchouni, D. Bachelet, N. McDowell, M. Vennetier, T. Kitzberger, A. Rigling, D. Breshears, E. H. Hogg, P. Gonzalez, R. Fensham, Z. Zhang, J. Castro, N. Demidov, J.-H. Lim, G. Allard, S. W. Running, A. Semerci, and N. Cobb. 2010. A global overview of drought and heat-induced tree mortality reveals emerging climate change risks for forests. Forest Ecology and Management 259:660-684. http://dx.doi. org/10.1016/j.foreco.2009.09.001

Allen, M. R., P. A. Stott, J. F. B. Mitchell, R. Schnur, and T. L. Delworth. 2000. Quantifying the uncertainty in forecasts of anthropogenic climate change. Nature 407:617-620. http://dx.doi. org/10.1038/35036559

Anandhi, A., A. Frei, D. C. Pierson, E. M. Schneiderman, M. S. Zion, D. Lounsbury, and and A. H. Matonse. 2011. Examination of change factor methodologies for climate impact assessment. Water Resources Research 47:W03501. http://dx.doi. org/10.1029/2010WR009104

Bader, M. K.-F., S. Leuzinger, S. G. Keel, R. T. W. Siegwolf, F. Hagedorn, P. Schleppi, and C. Körner. 2013. Central European hardwood trees in a high-CO2 future: synthesis of an 8-year forest canopy $\mathrm{CO}_{2}$ enrichment project. Journal of Ecology 101:1509-1519. http://dx.doi.org/10.1111/1365-2745.12149

Bayes, T., and M. Price. 1763. An essay towards solving a problem in the doctrine of chances. Philosophical Transactions of the Royal Society of London 53:370-418. http://dx.doi.org/10.1098/ $\underline{\text { rstl.1763.0053 }}$

Bernetti, I., C. Ciampi, C. Fagarazzi, and S. Sacchelli. 2011. The evaluation of forest crop damages due to climate change. An application of Dempster-Shafer method. Journal of Forest Economics 17:285-297. http://dx.doi.org/10.1016/j.jfe.2011.04.005

Bigler, C., O. Bräker, H. Bugmann, M. Dobbertin, and A. Rigling. 2006. Drought as an inciting mortality factor in Scots pine stands of the Valais, Switzerland. Ecosystems 9:330-343. http://dx.doi. org/10.1007/s10021-005-0126-2

Blennow, K., and J. Persson. 2009. Climate change: motivation for taking measure to adapt. Global Environmental Change 19:100-104. http://dx.doi.org/10.1016/j.gloenvcha.2008.10.003

Blennow, K., J. Persson, E. Persson, and M. Hanewinkel. 2016. Forest owners' response to climate change: university education trumps value profile. PLOS ONE 11:e0155137. http://dx.doi. org/10.1371/journal.pone.0155137 
Blennow, K., J. Persson, M. Tomé, and M. Hanewinkel. 2012. Climate change believing and seeing implies adapting. PLOS ONE 7:e50182. http://dx.doi.org/10.1371/journal.pone.0050182

Bolte, A., C. Ammer, M. Löf, P. Madsen, G.-J. Nabuurs, P. Schal, P. Spathelf, and J. Rock. 2009. Adaptive forest management in central Europe: climate change impacts, strategies and integrative concept. Scandinavian Journal of Forest Research 24:473-482. http://dx.doi.org/10.1080/02827580903418224

Bonan, G. B. 2008. Forests and climate change: forcings, feedbacks, and the climate benefits of forests. Science 320:1444-1449. http://dx.doi.org/10.1126/science.1155121

Borges, J. G., J. Garcia-Gonzalo, V. Bushenkov, M. E. McDill, S. Marques, and M. M. Oliveira. 2014. Addressing multicriteria forest management with Pareto Frontier methods: an application in Portugal. Forest Science 60:63-72. http://dx.doi.org/10.5849/ forsci.12-100

Bosselmann, A. S., J. B. Jacobsen, B. J. Thorsen, and E. D. Kjær. 2008. Climate change, uncertainty and the economic value of genetic diversity: a pilot study on methodologies. Working paper 31, Forest \& Landscape, University of Copenhagen, Copenhagen, Denmark.

Bouriaud, L., O. Bouriaud, C. Elkin, C. Temperli, C. Reyer, G. Duduman, I. Barnoaiea, L. Nichiforel, N. Zimmermann, and H. Bugmann. 2015. Age-class disequilibrium as an opportunity for adaptive forest management in the Carpathian Mountains, Romania. Regional Environmental Change 15:557-1568. http://dx. doi.org/10.1007/s10113-014-0717-6

Broadmeadow, M. S. J., D. Ray, and C. J. A. Samuel. 2005. Climate change and the future for broadleaved tree species in Britain. Forestry 78:145-161. http://dx.doi.org/10.1093/forestry/cpi014

Brunette, M., S. Costa, and F. Lecocq. 2014. Economics of species change subject to risk of climate change and increasing information: a (quasi-)option value analysis. Annals of Forest Science 71:279-290. http://dx.doi.org/10.1007/s13595-013-0281-0

Davis, M. B., and R. G. Shaw. 2001. Range shifts and adaptive responses to Quaternary climate change. Science 292:673-679. http://dx.doi.org/10.1126/science.292.5517.673

Dempster, A. P. 1967. Upper and lower probabilities induced by a multivalued mapping. Annals of Mathematical Statistics 38:325-339. http://dx.doi.org/10.1214/aoms/1177698950

Diaz-Nieto, J., and R. L. Wilby 2005. A comparison statistical downscaling and climate change factor methods: impacts on low flows in the River Thames, United Kingdom. Climatic Change 69:245-268. http://dx.doi.org/10.1007/s10584-005-1157-6

Elkin, C., A. G. Gutiérrez, S. Leuzinger, C. Manusch, C. Temperli, L. Rasche, and H. Bugmann. 2013. A $2{ }^{\circ} \mathrm{C}$ warmer world is not safe for ecosystem services in the European Alps. Global Change Biology 19:1827-1840. http://dx.doi.org/10.1111/gcb.12156

Ferreira, L., M. F. Constantino, J. G. Borges, and J. GarcíaGonzalo. 2012. A stochastic dynamic programming approach to optimize short-rotation coppice systems management scheduling: an application to eucalypt plantations under wildfire risk in Portugal. Forest Science 58:353-365. http://dx.doi.org/10.5849/ forsci.10-084
Ferreira, L., M. F. Constantino, J. G. Borges, and J. GarciaGonzalo. 2015. Addressing wildfire risk in a landscape-level scheduling model: an application in Portugal. Forest Science 61:266-277 http://dx.doi.org/10.5849/forsci.13-104

Ferreira, L., M. F. Constantino, J. G. Borges, J. Garcia-Gonzalo, and S. Barreiro. 2016. A climate change adaptive dynamic programming approach to optimize eucalypt stand management scheduling: a Portuguese application. Canadian Journal of Forest Research 46:1000-1008. http://dx.doi.org/10.1139/cjfr-2015-0329

Finkeldey, R., and M. Ziehe. 2004. Genetic implications of silvicultural regimes. Forest Ecoogy and Management 197:231-244. http://dx.doi.org/10.1016/j.foreco.2004.05.036

Fitzgerald, J., and M. Lindner, editors. 2013. Adapting to climate change in European forets- results of the MOTIVE project. Pensoft, Sofia, Bulgaria.

Garcia-Gonzalo, J., J. G. Borges, J. H. N. Palma, and A. Zuzibarreta-Gerendiai. 2014. A decision support system for management planning of Eucalyptus plantations facing climate change. Annals of Forest Science 71:187-199. http://dx.doi. org/10.1007/s13595-013-0337-1

Garcia-Gonzalo, J., C. Pais, J. Bachmatiuk, and A. Weintraub. 2016. Accounting for climate change in a forest planning stochastic optimization model. Canadian Journal of Forest Research46:1111-1121.http://dx.doi.org/10.1139/cjfr-2015-0468

Giorgetta, M. A., J. Jungclaus, C. Reick, S. Legutke, J. Bader, M. Böttinger, V. Brovkin, T. Crueger, M. Esch, K. Fieg, K. Glushak, V. Gayler, H. Haak, H. D. Hollweg, T. Ilyina, S. Kinne, L. Kornblueh, D. Matei, T. Mauritsen, U. Mikolajewicz, W. Mueller, D. Notz, F. Pithan, T. Raddatz, S. Rast, R. Redler, E. Roeckner, H. Schmidt, R. Schnur, J. Segschneider, K. D. Six, M. Stockhause, C. Timmreck, J. Wegner, H. Widmann, K. H. Wieners, M. Claussen, J. Marotzke, and B. Stevens. 2013. Climate and carbon cycle changes from 1850 to 2100 in MPI-ESM simulations for the Coupled Model Intercomparison Project phase 5. Journal of Advances in Modelling Earth Systems 5:572-597. http://dx.doi. org/10.1002/jame.20038

González-Olabarriaa, J. R., and T. Pukkala. 2011. Integrating fire risk considerations in landscape-level forest planning. Forest Ecology and Management 261:278-287. http://dx.doi.org/10.1016/ j.foreco.2010.10.017

Hamrick, J. L. 2004. Response of forest trees to global environmental changes. Forest Ecology and Management 197:323-335. http://dx.doi.org/10.1016/j.foreco.2004.05.023

Hanewinkel, M., D. A. Cullmann, M.-J. Schelhaas, G.-J. Nabuurs, and N. E. Zimmermann. 2013. Climate change may cause severe loss in the economic value of European forestland. Nature Climate Change 3:203-207. http://dx.doi.org/10.1038/nclimate1687

Hanewinkel, M., S. Hummel, and A. Albrecht. 2011. Assessing natural hazards in forestry for risk management: a review. European Journal of Forest Research 130:329-351. http://dx.doi. org/10.1007/s10342-010-0392-1

Hengeveld, G. M., M. Didion, S. Clerkx, C. Elkin, G.-J. Nabuurs, and M.-J. Schelhaas. 2015. The landscape-level effect of individual-owner adaptation to climate change in Dutch forests. 
Regional Environmental Change 15:1515-1529. http://dx.doi. org/10.1007/s10113-014-0718-5

Hickler, T., A. Rammig, and C. Werner. 2015. Modelling $\mathrm{CO}_{2}$ impacts on forest productivity. Current Forestry Report 1:69-80. http://dx.doi.org/10.1007/s40725-015-0014-8

Hoganson, H. M., and D. W. Rose. 1987. A model for recognizing forestwide risk in timber management scheduling. Forest Science $33: 268-272$.

Hoogstra, M. A. 2008. Coping with the long term: an empirical analysis of time perspectives, time orientations, and temporal uncertainty in forestry. Dissertation. University of Wageningen, Wageningen, The Netherlands.

Hülsmann, L., H. K. M. Bugmann, B. Commarmot, P. Meyer, S. Zimmermann, and P. Brang. 2016. Does one model fit all? Patterns of beech mortality in natural forests of three European regions. Ecological Applications 26:2465-2479. http://dx.doi. org/10.1002/eap.1388

Hyyppä, J., X. Yu, H. Hyyppä, M. Vastaranta, M. Holopainen, A. Kukko, H. Kaartinen, A. Jaakkola, M. Vaaja, J. Koskinen, and P. Alho. 2012. Advances in forest inventory using airborne laser scanning. Remote Sensing 4:1190-1207. http://dx.doi. org/10.3390/rs4051190

Intergovernmental Panel on Climate Change (IPCC). 2013. Climate change 2013: the physical science basis. Contribution of Working Group I to the Fifth Assessment report of the Intergovernmental Panel on Climate Change. T. F. Stocker, D. Qin, G.-K. Plattner, M. Tignor, S. K. Allen, J. Boschung, A. Nauels, Y. Xia, V. Bex and P. M. Midgley, editors. Cambridge University Press, Cambridge, UK.

Intergovernmental Panel on Climate Change (IPCC). 2014. Climate change 2014: impacts, adaptation, and vulnerability. Part A: global and sectoral aspects. Contribution of Working Group II to the Fifth Assessment report of the Intergovernmental Panel on Climate Change. C. B. Field, V. R. Barros, D. J. Dokken, K. J. Mach, M. D. Mastrandrea, T. E. Bilir, M. Chatterjee, K. L. Ebi, Y. O. Estrada, R. C. Genova, B. Girma, E. S. Kissel, A. N. Levy, S. MacCracken, P. R. Mastrandrea, and L. L. White, editors. Cambridge University Press, Cambridge, UK.

Jacobsen, J. B., and B. J. Thorsen. 2003. A Danish example of optimal thinning strategies in mixed-species forest under changing growth conditions caused by climate change. Forest Ecology and Management 180:375-388. http://dx.doi.org/10.1016/ $\underline{\mathrm{S} 0378-1127(02) 00652-7}$

Jøsang, A., and S. Pope. 2012. Dempster's rule as seen by little colored balls. Computational Intelligence 28:453-474. http://dx. doi.org/10.1111/j.1467-8640.2012.00421.x

Kinnunen, R., I. Lehtonen, J. Kas, R. Järcvelä, H. Poutamo, C. Wenzlaft, and J. Latus. 2013. Impact of climate change on the boreal forest in Finland and Sweden. HENWI workshop Report. University of Helsinki, Helsinki, Finland.

Kint, V., W. Aertsen, M. Campioli, D. Vansteenkiste, A. Delcloo, and B. Muys. 2012. Radial growth change of temperate tree species in response to altered regional climate and air quality in the period 1901-2008. Climatic Change 115:343-363. http://dx. doi.org/10.1007/s10584-012-0465-X
Klein, T., M. K.-F. Bader, S. Leuzinger, M. Mildner, P. Schleppi, R. T. W. Siegwolf, and C. Körner. 2016. Growth and carbon relations of mature Picea abies trees under 5 years of free air $\mathrm{CO}_{2}$ enrichment. Journal of Ecology 104:1720-1733. http://dx.doi. org/10.1111/1365-2745.12621

Kolström, M., M. Lindner, T. Vilén, M. Maroschek, R. Seidl, M. J. Lexer, S. Netherer, A. Kremer, S. Delzon, A. Barbati, M. Marchetti, and P. Corona. 2011. Reviewing the science and implementation of climate change adaptation measures in European forestry. Forests 2:961-982. http://dx.doi.org/10.3390/ $\underline{\text { f2040961 }}$

Kramer, K., J. Buiteveld, M. Forstreuter, T. Geburek, S. Leonardi, P. Menozzi, F. Povillon, M. J. Schelhaas, E. Teissier du Cros, and G. G. Vendramin. 2008. Bridging the gap between ecophysiological and genetic knowledge to assess the adaptive potential of European beech. Ecological Modelling 216:333-353. http://dx.doi.org/10.1016/j.ecolmodel.2008.05.004

Kramer, K., B. Degen, J. Buschbom, T. Hickler, W. Thuiller, M. T. Sykes and W. D. Winter. 2010. Modelling exploration of the future of European beech (Fagus sylvatica L.) under climate change - range, abundance, genetic diversity and adaptive response. Forest Ecology and Management 259:2213-2222. http:// dx.doi.org/10.1016/j.foreco.2009.12.023

Kramer, K., B. van der Werf, and M.-J. Schelhaas. 2015. Bring in the genes: genetic-ecophysiological modeling of the adaptive response of trees to environmental change. With application to the annual cycle. Frontiers in Plant Science 5. http://dx.doi. org/10.3389/fpls.2014.00742

Kremer, A., O. Ronce, J. J. Robledo-Arnuncio, F. Guillaume, G. Bohrer, R. Nathan, J. R. Bridle, R. Gomulkiewicz, E. K. Klein, K. Ritland, A. Kuparinen, G. Gerber, and S. Schueler. 2012 Long-distance gene flow and adaptation of forest trees to rapid climate change. Ecology Letters 15:378-392. http://dx.doi. org/10.1111/j.1461-0248.2012.01746.x

Lamy, J.-B., L. Bouffier, R. Burlet, C. Plomion, H. Cochard, and D. Sylvain. 2011. Uniform selection as a primary force reducing population genetic differentiation of cavitation resistance across a species range. PLoS ONE 6:e23476. http://dx.doi.org/10.1371/ journal.pone.0023476

Lamy, J.-B., S. Delzon, P. S. Bouche, R. Alia, G. G. Vendramin, H. Cochard, and C. Plomion. 2014. Limited genetic variability and phenotypic plasticity detected for cavitation resistance in a Mediterranean pine. New Phytologist 201:874-886. http://dx.doi. org/10.1111/nph.12556

Lindner, M., J. B. Fitzgerald, N. Zimmermann, C. Reyer, S. Delzon, E. van der Maaten, M. J. Schelhaas, P. Lasch, J. Eggers, M. van der Maaten-Theunissen, F. Suckow, A. Psomas, B. Poulter, and M. Hanewinkel. 2014. Climate change and European forests: what do we know, what are the uncertainties, and what are the implications for forest management? Journal of Environmental Management 146:69-83. http://dx.doi.org/10.1016/j.jenvman.2014.07.030

Lindroth, A., F. Lagergren, A. Grelle, L. Klemedtsson, O. Langvall, P. Weslien, and J. Tuulik. 2009. Storms can cause Europe-wide reduction in forest carbon sink. Global Change Biology 15:346-355. http://dx.doi.org/10.1111/j.1365-2486.2008.01719. $\underline{x}$ 
Manusch, C., H. Bugmann, C. Heiri, and A. Wolf. 2012. Tree mortality in dynamic vegetation models - a key feature for accurately simulating forest properties. Ecological Modelling 243:101-111. http://dx.doi.org/10.1016/j.ecolmodel.2012.06.008

McDowell, N. G., D. J. Beerling, D. D. Breshears, R. A. Fisher, K. F. Raffa, and M Stitt. 2011. The interdependence of mechanisms underlying climate-driven vegetation mortality. Trends in Ecology and Evolution 26:523-532. http://dx.doi. org/10.1016/j.tree.2011.06.003

Nakicenovic, N., J. Alcamo, G. Davis, B. de Vries, J. Fenhann, S. Gaffin, K. Gregory, A. Gruble, T. Y. Jung, T. Kram, E. L. La Rovere, L. Michaelis, S. Mori, T. Morita, W. Pepper, H. M. Pitcher, L. Price, K. Riahi, A. Roehrl, H. H. Rogner, A. Sankovski, M. Schlesinger, P. Shukla, S. J. Smith, R. Swart, S. van Rooijen, N. Victor, and Z. Dadi. 2000. Special report on emissions scenarios. Cambridge University Press, Cambridge, UK.

Oliet, J., R. Planelles, M. L. Arias, and F. Artero. 2002. Soil water content and water relations in planted and naturally regenerated Pinus halepensis Mill. seedlings during the first year in semiarid conditions. New Forests 23:31-44. http://dx.doi.org/10.1023/ A:1015668815037

Palma, J. H. N., J. A. Paulo, S. P. Faias, J. Garcia-Gonzalo, J. G. Borges, and M. Tomé. 2015. Adaptive management and debarking schedule optimization of Quercus suber L. stands under climate change: case study in Chamusca, Portugal. Regional Environmental Change 15:1569-1580. http://dx.doi.org/10.1007/ s10113-015-0818-X

Petr, M., L. G. J. Boerboom, D. Ray, and A. van der Veen. 2015. New climate change information modifies frames and decisions of decision-makers: an exploratory study in forest planning. Regional Environmental Change 16:161-1170.

Petr, M., L. G. J. Boerboom, A. van der Veen, and D. Ray. 2014. A spatial and temporal drought risk assessment of three major tree species in Britain using probabilistic climate change projections. Climatic Change 124:791-803. http://dx.doi. org/10.1007/s10584-014-1122-3

Plantinga, A. J. 1998. The optimal timber rotation: an option value approach. Forest Science 44(2):192-202.

Prato, T. 2009. Adaptive management of natural systems using fuzzy logic. Environmental Modelling \& Software 24:940-944. http://dx.doi.org/10.1016/j.envsoft.2009.01.007

Probert, W. J. M., C. E. Hauser, E. McDonald-Madden, M. C. Runge, P. W/. J. Baxter, and H. P. Possingham. 2011. Managing and learning with multiple models: objectives and optimization algorithms. Biological Conservation 144:1237-1245. http://dx.doi. org/10.1016/j.biocon.2010.07.031

Pukkala, T., and S. Kellomäki. 2012. Anticipatory versus adaptive optimization of stand management when tree growth and timber prices are stochastic. Forestry 85:463-472. http://dx.doi. org/10.1093/forestry/cps043

Ray, D., S. Bathgate, M. Moseley, P. Taylor, B. Nicoll, S. Pizzirani, and B. Gardiner. 2015. Comparing the provision of ecosystem services in plantation forests under alternative climate change adaptation management options in Wales. Regional Environmental Change 15:1501-1513. http://dx.doi.org/10.1007/s10113-014-0644-6
Reyer C. P. O., S. Bathgate, K. Blennow, J. G. Borges, H. Bugmann, S. Delzon, S. P. Faias, J. Garcia-Gonzalo, B. Gardiner, J. R. Gonzalez-Olabarria, C. Gracia, J. G. Hernández, S. Kellomäki, K. Kramer, M. J. Lexer, M. Lindner, E. van der Maaten, M. Maroschek, B. Muys, B. Nicoll, M. Palahi, J. H. N. Palma, J. A. Paulo, H. Peltola, T. Pukkala, W. Rammer, D. Ray, S. Sabaté, M. J. Schelhaas, R. Seidl, C. Temperli, M. Tomé, R. Yousefpour, N. E. Zimmermann, and M. Hanewinkel. 2017. Are forest disturbances amplifying or canceling out climate change-induced productivity changes in European forests? Environmental Research Letters 12:034027. http://dx.doi.org/10.1088/1748-9326/ aa5ef1

Reyer, C. P. O., P. Lasch-Born, F. Suckow, M. Gutsch, A. Murawski, and T. Pilz. 2014. Projections of regional changes in forest net primary productivity for different tree species in Europe driven by climate change and carbon dioxide. Annals of Forest Science 71:211-225. http://dx.doi.org/10.1007/s13595-013-0306-8

Reyer, C. P. O., S. Leuzinger, A. Rammig, A. Wolf, R. P. Bartholomeus, A. Bonfante, F. De Lorenzi, M. Dury, P. Gloning, R. Abou Jaoudé, T. Klein, T. M. Kuster, M. Martins, G. Niedrist, M. Riccardi, G. Wohlfahrt, P. De Angelis, G. de Dato, L. François, A. Menzel, and M. Pereira. 2013. A plant's perspective of extremes: terrestrial plant responses to changing climatic variability. Global Change Biology 19:75-89. http://dx.doi. org/10.1111/gcb.12023

San-Miguel-Ayanz, S., J. Manuel-Moreno, and A. Camia. 2013. Analysis of large fires in European Mediterranean landscapes: lessons learned and perspectives. Forest Ecology and Management 294:11-22. http://dx.doi.org/10.1016/i.foreco.2012.10.050

Schelhaas, M.-J., G.-J. Nabuurs, G. Hengeveld, C. Reyer, M. Hanewinkel, N. E. Zimmermann, and D. Cullmann. 2015. Alternative forest management strategies to account for climate change-induced productivity and species suitability changes in Europe. Regional Environmental Change 15:1581-1594. http://dx. doi.org/10.1007/s10113-015-0788-Z

Schou, E., J. B. Jacobsen, and K. L. Kristensen. 2012. An economic evaluation of strategies for transforming even-aged into near-natural forestry in a conifer-dominated forest in Denmark. Forest Policy and Economics 20:89-98. http://dx.doi.org/10.1016/ j.forpol.2012.02.010

Schou, E., B. J. Thorsen, and J. B. Jacobsen. 2015. Regeneration decisions in forestry under climate change related uncertainties and risks: effects of three different aspects of uncertainty. Forest Policy and Economics 50:11-19. http://dx.doi.org/10.1016/j. forpol.2014.09.006

Seidl, R, C. S. Eastaugh, K. Kramer, M. Maroschek, C. Reyer, J. Socha, G. Vacchiano, T. Zlatanov, H. Hasenauer. 2013. Scaling issues in forest ecosystem management and how to address them with models. European Journal of Forest Research 132:653-666. http://dx.doi.org/10.1007/s10342-013-0725-y

Seidl, R., P. M. Fernandes, T. F. Fonseca, F. Gillet, A. M. Jönsson, K. Merganičová, S. Netherer, A. Arpaci, J.-D. Bontemps, H. Bugmann, J. R. González-Olabarria, P. Lasch, C. Meredieu, F. Moreira, M.-J. Schelhaas, and F. Mohren. 2011. Modelling natural disturbances in forest ecosystems: a review. Ecological Modelling 222:903-924. http://dx.doi.org/10.1016/i.ecolmodel.2010.09.040 
Seidl, R., M.-J. Schelhaas, W. Rammer, and P. J. Verkerk. 2014. Increasing forest disturbances in Europe and their impact on carbon storage. Nature Climate Change 4:806-810. http://dx.doi. org/10.1038/nclimate2318

Smit, B., and J. Wandel. 2006. Adaptation, adaptive capacity and vulnerability. Global Environmental Change 16:282-292. http://dx. doi.org/10.1016/j.gloenvcha.2006.03.008

Spittlehouse, D., and R. B. Stewart. 2003. Adapting to climate change in forest management. Journal of Ecosystems Management 4:7-17.

Steel, B., P. List, D. Lach, and B. Shindler. 2004. The role of scientists in the environmental policy process: a case study from the American west. Environmental Science \& Policy 7:1-13. http:// dx.doi.org/10.1016/j.envsci.2003.10.004

Temperli, C., H. Bugmann, and C. Elkin. 2012. Adapative management for competing forest goods and services under climate change. Ecological Applications 22:2065-2077. http://dx. doi.org/10.1890/12-0210.1

Temperli, C., J. Zell, H. Bugmann, and C. Elkin. 2013. Sensitivity of ecosystem goods and services projections of a forest landscape model to initialization data. Landscape Ecology 28:1337-1352. http://dx.doi.org/10.1007/s10980-013-9882-0

Thompson, J. R., A. Wiek, F. J. Swanson, S. R. Carpenter, N. Fresco, T. Hollingsworth, T. A. Spies, and D. A. Foster. 2012. Scenario studies as a synthetic and integrative research activity for long-term ecological research. BioScience 62:367-376. http:// dx.doi.org/10.1525/bio.2012.62.4.8

Thorsen, B. 1999a. Afforestation as a real option: some policy implications. Forest Science 45:171-178.

Thorsen, B. 1999b. Progressive income taxes and option values: the case of a farmer who owns a forest. Journal of Forest Economics 5:217-234.

Trasobares, A., A. Zingg, L. Walthert, and C. Bigler. 2016. A climate-sensitive empirical growth and yield model for forest management planning of even-aged beech stands. European Journal of Forest Research 135:263-282. http://dx.doi. org/10.1007/s10342-015-0934-7

United Nations Economic Commission for Europe and Food and Agriculture Organization(UNECE FAO). 2011. State of Europe's forests. 2011: status and trends in sustainable forest management in Europe. UNECE, Geneva, Switzerland and FAO, Rome, Italy. [online] URL: http://www.foresteurope.org/documentos/

State_of_Europes_Forests_2011_Report_Revised_November_2011. pdf

Vanoni, M., H. Bugmann, M. Nötzli, and C. Bigler. 2016. Drought and frost contribute to abrupt growth decreases before tree mortality in nine temperate tree species. Forest Ecology and Management 382:51-63. http://dx.doi.org/10.1016/j.foreco.2016.10.001

Vitasse, Y., S. Delzon, C. C. Bresson, R. Michalet, and A. Kremer. 2009. Altitudinal differentiation in growth and phenology among populations of temperate-zone tree species growing in a common garden. Canadian Journal of Forest Research 39:1259-1269. http:// dx.doi.org/10.1139/X09-054
Walentowski, H., E. D. Schulze, M. Teodosiu, O. Bouriaud, A. von Heßberg, H. Bußler, L. Baldauf, I. Schulze, J. Wäldchen, R. Böcker, S. Herzog, and W. Schulze. 2013. Sustainable forest management of Natura 2000 sites: a case study from a private forest in the Romanian Southern Carpathians. Annals of Forest Research 56:217-245.

Wright, J. W. 1976. Introduction to forest genetics. Academic Press, New York, New York, USA.

Wunder, J., B. Brzeziecki, H. Żybura, B. Reineking, C. Bigler, and H. Bugmann. 2008. Growth-mortality relationships as indicators of life-history strategies: a comparison of nine tree species in unmanaged European forests. Oikos 117:815-828. http://dx. doi. org/10.1111/j.0030-1299.2008.16371.x

Yousefpour, R., M. Didion, J. B. Jacobsen, H. Meilby, G. M. Hengeveld, M.-J. Schelhaas, and B. J. Thorsen. 2015. Modelling of adaptation to climate change and decision-makers behaviours for the Veluwe forest area in the Netherlands. Forest Policy and Economics 54:1-10. http://dx.doi.org/10.1016/j.forpol.2015.02.002

Yousefpour, R., and M. Hanewinkel. 2015. Forestry professionals' perceptions of climate change, impacts and adaptation strategies for forests in south-west Germany. Climatic Change 130:273-286. http://dx.doi.org/10.1007/s10584-015-1330-5

Yousefpour, R., J. B. Jacobsen, H. Meilby, and B. J. Thorsen. 2014. Knowledge update in adaptive management of forest resources under climate change: a Bayesian simulation approach. Annals of Forest Science 71:301-312. http://dx.doi.org/10.1007/s13595-013-0320$\underline{\mathrm{X}}$

Yousefpour, R., J. B. Jacobsen, B. J. Thorsen, H. Meilby, M. Hanewinkel, and K. Oehler. 2012. A review of decision-making approaches to handle uncertainty and risk in adaptive forest management under climate change. Annals of Forest Science 69:1-15. http://dx.doi.org/10.1007/s13595-011-0153-4

Yousefpour, R., C. Temperli, H. Bugmann, C. Elkin, M. Hanewinkel, H. Meilby, J. B. Jacobsen, and B. J. Thorsen. 2013. Updating beliefs and combining evidence in adaptive forest management under climate change: A case study of Norway spruce (Picea abies L. Karst) in the Black Forest, Germany. Journal of Environmental Management 122:56-64. http://dx.doi. org/10.1016/j.jenvman.2013.03.004

Zell, J., and M. Hanewinkel. 2015. How treatment, storm events and changed climate affect productivity of temperate forests in SW Germany. Regional Environmental Change 15:1531-1542. http://dx.doi.org/10.1007/s10113-015-0777-2

Zurbriggen, N., J. E. M. S. Nabel, M. Teich, P. Bebi, and H. Leschcke. 2014. Explicit avalanche-forest feedback simulations improve the performance of a coupled avalanche-forest model. Ecological Complexity 17:56-66. http://dx.doi.org/10.1016/j. ecocom.2013.09.002 
Appendix 1 Climate projections

Table A1.1 List of climate models used in the simulation of case studies. Both GCM and RCM models are used to realize the climate change scenarios using multiple sources (Source: Hanewinkel et al. 2013).

\begin{tabular}{|l|l|l|l|}
\hline \multicolumn{1}{|c|}{ GCM } & \multicolumn{1}{c|}{ RCM } & \multicolumn{1}{c|}{ SRES } & \multicolumn{1}{c|}{ Source } \\
\hline CGCM2 & - & A1Fi & CRU - TYN SC $1.0^{1}$ \\
\hline CSIR02 & - & A1Fi & CRU - TYN SC $1.0^{1}$ \\
\hline PCM & - & A1Fi & CRU - TYN SC $1.0^{1}$ \\
\hline HadCM3 & - & A1Fi & CRU - TYN SC $1.0^{1}$ \\
\hline CGCM2 & - & B2 & CRU - TYN SC $1.0^{1}$ \\
\hline CSIR02 & - & B2 & CRU - TYN SC $1.0^{1}$ \\
\hline PCM & - & B2 & CRU - TYN SC $1.0^{1}$ \\
\hline HadCM3 & - & B2 & CRU - TYN SC $1.0^{1}$ \\
\hline Arpege & Hirham & A1B & ENSEMBLES 2 \\
\hline HadCM3 & HadRM3Q0 & A1B & ENSEMBLES 2 \\
\hline ECHM5 & CLM & A1B & ENSEMBLES \\
\hline CCSM3 & RC30 & A1B & ENSEMBLES \\
\hline
\end{tabular}

${ }^{1}$ Climate Research Unit: $\quad$ http://www.cru.uea.ac.uk/cru/data/hrg

${ }^{2}$ ENSEMBLES project: $\quad \underline{\mathrm{http}} / / /$ ensemblesrt3.dmi.dk

${ }^{3}$ Max Planck Institute: $\quad$ http://cera-www.dkrz.de

For simulation runs of each case study data from regional circulation model (RCM) climate projections have been used. For example, in the study area in southeastern Veluwe in the Netherlands, with elevations ranging from ca. 20-100 meters a.s.1., the following table summarizes the climate properties for the realization of the A1B emission scenario as generated using three different models. Each RCM was fed at the simulation region boundary by data from different Global Circulation Models (GCM) that were part of the model projections published in IPCC's fourth assessment report (IPCC 2007). RCM simulations were provided by the EU project ENSEMBLES. More details about climate projections can be found in Hanewinkel et al. (2013).

Table A1.2 An example of climate data produced by RCMs and used for further climate and forest interactions modelling

\begin{tabular}{|l|l|l|l|l|l|}
\hline & & $\begin{array}{l}\text { Temperatur } \\
\mathrm{e}\end{array}$ & {$\left[^{\circ} \mathrm{C}\right]$} & Precipitation & {$[\mathrm{mm}]$} \\
\hline $\begin{array}{l}\text { Climate model: } \\
\text { scenario }\end{array}$ & $\begin{array}{l}\text { Degree of } \\
\text { change }\end{array}$ & Mean & Minimum & $\begin{array}{l}\text { Mean } \\
\text { annual }\end{array}$ & $\begin{array}{l}\text { Mean } \\
\text { summer }\end{array}$ \\
\hline $\begin{array}{l}\text { RCA30: A1B } \\
(2081-2100)\end{array}$ & No-/Low & $\begin{array}{l}11.24 \\
(0.64)\end{array}$ & $\begin{array}{l}3.02 \\
(1.35)\end{array}$ & $\begin{array}{l}809.6 \\
(83.4)\end{array}$ & $\begin{array}{l}372.0 \\
(67.6)\end{array}$ \\
\hline $\begin{array}{l}\text { CLM: A1B } \\
(\text { 2081-2100) }\end{array}$ & Moderate & $\begin{array}{l}12.27 \\
(1.06)\end{array}$ & $\begin{array}{l}4.59 \\
(1.75)\end{array}$ & $\begin{array}{l}807.5 \\
(78.4)\end{array}$ & $\begin{array}{l}344.0 \\
(59.8)\end{array}$ \\
\hline HadRM3Q0: A1B & High & 12.64 & 3.28 & 734.5 & 331.3 \\
\hline
\end{tabular}




\begin{tabular}{|l|l|l|l|l|l|}
\hline $\mathbf{( 2 0 8 1 - 2 1 0 0 )}$ & & $(1.28)$ & $(2.23)$ & $(120.4)$ & $(93.5)$ \\
\hline
\end{tabular}

RCA30: Model projection by the Swedish Meteorological and Hydrological Institute using GCM data from CCSM3 as input CLM: Model projection by the Max-Planck Institute (MPI) using GCM data from ECHAM5 as input

HadRM3Q0: Model projection by Met office Hadley centre (HC) using GCM data from HadCM3 as input

* Summer = April-September

Numbers in parenthesis are standard deviation of mean figures in the table

\section{LITERATURE CITED:}

1. Hanewinkel, M., D. A. Cullmann, M. J. Schelhaas, G. J. Nabuurs, and N. Zimmermann 2013. Climate change may cause severe loss in the economic value of European forest land. Nature Climate Change 3:203-207.

2. IPCC. 2007. Climate Change 2007: The physical science basis. Contribution of working group $i$ to the fourth assessment report of the intergovernmental panel on climate change, Cambridge, UK and New York, NY, USA: Cambridge University Press. 
Appendix 2 Forest models

Table A2.1 Forest growth models applied in case studies and associates risks

\begin{tabular}{|c|c|c|c|c|}
\hline Model & $\begin{array}{l}\text { Area of } \\
\text { application }\end{array}$ & Structure & Processes & Risks \\
\hline $\begin{array}{l}G \& Y^{*} \\
\text { Maritime } \\
\text { Pine }\end{array}$ & $\begin{array}{l}\text { Mediterranean, } \\
\text { Portugal }\end{array}$ & Empirical & $\begin{array}{l}\text { Growth and } \\
\text { Yield }\end{array}$ & Fire \\
\hline Glob3PG & $\begin{array}{l}\text { Mediterranean, } \\
\text { Portugal }\end{array}$ & Process-based & $\begin{array}{l}\text { Growth, Climate } \\
\text { change, } \\
\text { fertilization, }\end{array}$ & $\begin{array}{l}\text { Disease (e.g. } \\
\text { pests) }\end{array}$ \\
\hline SUBER & $\begin{array}{l}\text { Mediterranean, } \\
\text { Portugal }\end{array}$ & Empirical & $\begin{array}{l}\text { Growth and } \\
\text { Yield, Climate } \\
\text { Change }\end{array}$ & \\
\hline LandClim & $\begin{array}{l}\text { temperate, } \\
\text { Germany }\end{array}$ & Process-based & $\begin{array}{l}\text { Growth under } \\
\text { Climate Change) }\end{array}$ & $\begin{array}{l}\text { Fire, wind, bark } \\
\text { beetle }\end{array}$ \\
\hline PICUS & Alpine, Austria & Process-based & $\begin{array}{l}\text { Growth under } \\
\text { Climate Change }\end{array}$ & $\begin{array}{l}\text { bark beetles, } \\
\text { storms }\end{array}$ \\
\hline FinnFor & Boreal, Finnland & Process-based & $\begin{array}{l}\text { Growth, climate } \\
\text { change, }\end{array}$ & wind damages \\
\hline $\begin{array}{l}G \& Y^{*} \\
\text { Beech }\end{array}$ & $\begin{array}{l}\text { Temperate, } \\
\text { Switzerland }\end{array}$ & $\begin{array}{l}\text { Empirical \& } \\
\text { Climate sensitive }\end{array}$ & $\begin{array}{l}\text { Growth under } \\
\text { climate change, }\end{array}$ & - \\
\hline $\begin{array}{l}\text { G \& } Y^{*} \\
\text { Pine sp. }\end{array}$ & $\begin{array}{l}\text { Mediterranean, } \\
\text { Spain }\end{array}$ & Empirical & $\begin{array}{l}\text { Growth and } \\
\text { Yield, } \\
\text { management } \\
\text { systems }\end{array}$ & -Fire \\
\hline PICUS & $\begin{array}{l}\text { Continental, } \\
\text { Bulgaria }\end{array}$ & Process-based & $\begin{array}{l}\text { Growth and } \\
\text { regeneration } \\
\text { under Climate } \\
\text { Change }\end{array}$ & \\
\hline LandClim & $\begin{array}{l}\text { Atlantic- } \\
\text { mediterranian, } \\
\text { The nethelands }\end{array}$ & Process-based & $\begin{array}{l}\text { Growth under } \\
\text { Climate Change) }\end{array}$ & Fire, wind \\
\hline LandClim & $\begin{array}{l}\text { Continental- } \\
\text { mountainous, } \\
\text { Romania }\end{array}$ & Process-based & $\begin{array}{l}\text { Growth under } \\
\text { Climate Change }\end{array}$ & \\
\hline Vidar & $\begin{array}{l}\text { Atlantic- } \\
\text { temperate, } \\
\text { Denmark }\end{array}$ & Empirical & $\begin{array}{l}\text { Growth and } \\
\text { Yield }\end{array}$ & Wind \\
\hline
\end{tabular}




\begin{tabular}{|l|l|l|l|l|}
\hline $\begin{array}{l}\text { UK Forestry } \\
\text { models }\end{array}$ & $\begin{array}{l}\text { Atlantic- } \\
\text { temperate, UK }\end{array}$ & $\begin{array}{l}\text { Empirical \& } \\
\text { Climate sensitive }\end{array}$ & $\begin{array}{l}\text { Growth and } \\
\text { Yield, Diversity, } \\
\text { Biomass, } \\
\text { Employment }\end{array}$ & Wind \\
\hline
\end{tabular}

G \& Y*: Growth and Yield forest model

\section{Brief introduction to $\mathbf{G} \& \mathbf{Y}$ models:}

Glob3PG: Glob3PG is a process-based model that takes advantage of 3PG's flexibility and ability to predict changes in growing conditions under several environmental conditions (e.g. climate change, fertilization, Tomé at al. 1998) and of GLOBULUS 3.0's prediction capacity under current conditions. The outcome from the proposed model Glob3PG, may: i) simulate the effect of intensive silvicultural practices (i.e shorter rotations, initial stand density), ii) simulate growth under climate change, iii) provide detailed stand structure information (diameter distribution, merchantable volumes to any top diameter) and iv) reflect the impact of pests and diseases on yield.

G \& Y model for maritime pine: In the case of the Leiria National Forest, an empirical model for predicting the growth of maritime pine and for understory growth (i.e. shrubs) was used. In addition, a wildfire risk model (Marques et al. 2012) and a post-fire mortality model (GarciaGonzalo et al. 2011) were used to estimate potential loss of timber in the area. Especially important is the inclusion of understory growth in the predictions as it has a big impact in the wildfire risk (Ferreira et al. 2015, Garcia-Gonzalo et al. 2012).

SUBER is an empirical individual tree model SUBER (Paulo 2011, Tomé 2004) and was used to project the growth and yield of trees and its cork for all spatial scales considered in the case study area. The model uses site index as a proxy for environmental conditions and this variable is included in several equations such as the mortality function and in the age-independent difference equation for modeling cork oak diameter growth (Tomé et al. 2006, Tomé 2004). Cork growth has been shown to be reduced by more frequent droughts and higher temperatures (Caritat et al. 2000), with direct impacts on cork thickness and the consequent cork production and such differences were evaluated in the case study (Palma et al. 2015).

LandClim: For the modelling of forest state evolution in the Black Forest area, a process-based forest landscape model LandClim was applied (Schumacher and Bugmann 2006). LandClim simulates forest biomass productivity and risks i.e. windthrow, fire, and natural mortality. The management actions regarded in developing AFM strategies were silvicultural interventions regeneration, thinning, and harvest. A combination of a set of these interventions over a planning horizon defined an AFM strategy to reach certain goals e.g. higher resistance, higher productivity, reduced risks. LandClim is further developed and calibration for the simulation of forest growth and yielding in different bioclimatic zones i.e. in Veluwe, the Netherlands (atlantic-mediterannian) and Carpathian mountainous forest areas in Romania (Carpathian mountainous).

PICUS: To apply AFM to Alpine forests, a well-developed model PICUS (Lexer and Brooks 2005) was used to simulate the forest biomass and wood volume productivity subject to the risks of bark beetles and storms. AFM strategies were defined as establishing demanded regeneration and growth control by harvest. Furthermore, PICUS is calibrated for coppice and 
coppice with standard Oak (Q. petrea, Q. cerris,Q. frainetto) and Pine (Pinus nigra) forests in Panagyurishte, Bulgaria to simulate AFM strategies.

FinnFor: In a Boreal area in southern Finland, a Finnish forest simulation model FinnFor (Kellomäki and Väisänen 1997) was used. FinnFor applies a forest management model MONSU (Pukkala 2014) and forcasts forest growth and mortality under diverse set of silvicultural interventions and integrated wind damage explicitly in the modelling process. FinnFor aims at maximizing timber and biomass production form finish commercial boreal forests.

G \& Y for European beech: this model combines traditional models for the predictions of forest productivity over time with a climate factor ADI (area drought index) to develop a climate sensitive empirical growth model for beech in Switzerland. The model outcomes can be used to evaluate the impact of thinning and harvesting on the forest stands and different site classes under changing climate conditions.

G \& Y model for Pine species (Pinus sylvestris L., Pinus nigra Arn., and Pinus halepensis)in Catalonia, north-east Spain is an individual tree model and simulates the effect of even-aged and uneven-aged forest management on stand development (Trasobares et al. 2004a, 2004b, González-Olabarria and Pukkala 2011). Moreover, an endogenous fire spread simulator is developed to predict the damage on forest stand and productivity interactively (GonzálezOlabarria and Pukkala 2011).

Vidar: a dynamic yield table program (Nord-Larsen et al. 2009) enabling the user to customize tables to different growth conditions and thinning regimes in Denmark. Simulations can only be made for even-aged stands. Therefore, we adjusted the model to uneven-aged and sized modelling was needed: to estimate the mean harvest diameter, standing volume and thinning volume (Schou et al. 2012).

UK forestry models: at the core of UK forestry models is UK yield model (Matthews 2008 ). It uses the yield classes data provided by an Ecological Site Classification, Pyatt et al. (2001), driven by regional climate data to predict stand development (tree height, diameter, volume and stocking density) over a rotation. Stand variables from forest yield became inputs to the UK wind risk model ForestGALES (Gardiner and Quine 2000) to calculate a wind damage risk score. Assortment models - ASORT - were used to determine the volume of saw-logs and small roundwood. BSORT (McKay et al. 2003) is a model to partition biomass and was used to estimate carbon stocks. A set of indicators e.g. timber production, biomass production, windd risk, species diversity are analysed to judge about the provisioning of ecosystems services upon applying BAU and adaptation strategies.

\section{LITERATURE CITED:}

1. Ferreira, L., M. Constantino, J. G. Borges, and J. Garcia-Gonzalo. 2015. Addressing Wildfire Risk in a Landscape-Level Scheduling Model: An Application in Portugal. Forest Science 61:266-277.

2. Garcia-Gonzalo, J., A. Zubizarreta-Gerendiain, A. Ricardo, S. Marques, B. Botequim,J. G. Borges, M. M. Oliveira, M. Tomé, and L. M. C. Pereira. 2012. Modelling wildfire risk in pure and mixed forest stands in Portugal. Allgemeine Forst- und Jagdzeitung 183:238-248.

3. Caritat, A., E. Gutierrez, and M. Molinas. 2000. Influence of weather on cork-ring width. Tree Physiology 20:893-900. 
4. Garcia-Gonzalo, J., S. Marques, J. G. Borges, B. Botequim, M. M. Oliveira, J. Tomé, J., and M. Tomé. 2011. A three-step approach to post-fire mortality modelling in Maritime pine (Pinus pinaster Ait) stands for enhanced forest planning in Portugal. Forestry. 84, 197-206

5. Kellomäki, S., and H. Väisänen. 1997. Modelling the dynamics of the forest ecosystem for climate change studies in the boreal conditions. Ecological Modelling 97:121-140.

6. Lexer, M.J., and R. T. Brooks. 2005. Decision support for multiple purpose forestry. Forest Ecology and Management 207:1-3.

7. Marques, S., B. Botequim, J. Garcia-Gonzalo, J. G. Borges, M. Tomé, and M. M. Oliveira. 2012. Assessing wildfire risk probability in Pinus pinaster Ait. stands in Portugal. Forest Systems 21:111-120.

8. McKay, H., J. B. Hudson, and R. J. Hudson. 2003. Woodfuel resource in Britain. Department of Trade and Industry Publication London.

9. Matthews, R. W. 2008. Forest yield. Forestry Commission, Edinburgh.

10. Nord-Larsen, T., H. Meilby, J. P. Skovgaards, and V. K. Johannsen. 2009. Development f VIDARa growth model for Danish forest tree species. Svkov \& Landskap, University of Copenhagen.

11. Pukkala, T. 2004. Dealing with Ecological Objectives in the Monsu Planning System. Silva Lusitana. 1:1-15.

12. Pyatt, D.G., D. Ray, and J. Fletcher. 2001. An ecological site classification for forestry in Great Britain. Forestry Commission, Edinburgh.

13. Schou, E., J. B. Jacobsen, and K. L. Kristensen. 2012. An economic evaluation of strategies for transforming even-aged into near-natural forestry in a conifer-dominated forest in Denmark. Forest Policy and Economics 20:89-98.

14. Schumacher, S., and H. Bugmann. 2006. The relative importance of climatic effects, wildfires and management for future forest landscape dynamics in the Swiss Alps. Global Change Biology 12:1435-1451.

15. Tomé, M. M., A. O. Falcão, and A. Amaro. 1998. GLOBULUS V.1.0.0: a regionalized growth model for eucalypt plantations in Portugal. In: Ortega A. and Gezan S. (Eds.), Modelling Growth of Fast-Grown Tree Species, Proceedings of IUFRO Conference. Valdivia, Chile: IUFRO, pp. 138145.

16. Trasobares, A., T. Pukkala, and J. Miina. 2004a. Growth and yield model for uneven-aged mixtures of Pinus sylvestris L. and Pinus nigra Arn. in Catalonia, north-east Spain. Annals of Forest Science 61:9-25.

17. Trasobares, A., M. Tome, and J. Miina. 2004b. Growth and yield model for Pinus halepensis in Catalonia, north-east Spain. Forest Ecology and Management. 203:49-62.

18. Trasobares, A., B. J. Thorsen, J. B. Jacobsen, R. Yousefpour, and H. Bugmann. 2012. Optimizing the management of even-aged beech stands under climate change uncertainty. Conference Presentation Online: Tackling climate change: the contribution of forest scientific knowledge, TOURS France, 21-24 May, 2012 


\section{Appendix 3 Adaptation strategies}

Table A3.1 Summary of case studies' management strategies including BAU (Business As Usual) and adaptive management options

\begin{tabular}{|c|c|c|}
\hline Case study & BAU & Adaptive management options \\
\hline $\begin{array}{l}\text { Black Forest } \\
\text { Germany }\end{array}$ & $\begin{array}{l}\text { BAU: Age-Class system } \\
\text { (Even-aged } \quad \text { Norway } \\
\text { spruce) }\end{array}$ & $\begin{array}{l}\text { A1: Mixed forest for a reactive management } \\
\text { (Promotion of spruce and silver fir) } \\
\text { A2: Natural vegetation } \\
\text { (doing nothing) } \\
\text { A3: Admixing with Douglas/silver fir }\end{array}$ \\
\hline $\begin{array}{l}\text { Chamusca, } \\
\text { Portugal }\end{array}$ & $\begin{array}{l}\text { Eucalyptus rotation length } 9 \\
\text { yr, } 2 \text { coppice cycles }\end{array}$ & $\begin{array}{l}\text { Different prescriptions were automatically } \\
\text { constructed for eucalypt stands by combining } \\
\text { changes in rotation lengths, and number of coppice } \\
\text { cycles. New rotation lengths ranged from } 9 \text { to } 15 \\
\text { years and number of coppice cycles ranged from } 1 \\
\text { to } 3 \text {. }\end{array}$ \\
\hline $\begin{array}{l}\text { Chamusca, } \\
\text { Paortugal }\end{array}$ & $\begin{array}{l}\text { Cork oak bark extractions } \\
\text { cycles of } 9 \text { years }\end{array}$ & $\begin{array}{l}\text { Different prescriptions were automatically } \\
\text { constructed for cork oak stands by combining 1) } \\
\text { changes in extraction cycles }(9-11), 2) \text { decrease in } \\
\text { debarking intensity (height of debarking), 3) } \\
\text { increase tree density in forest stands up to } 300 \\
\text { trees/ha when tree cover is below } 58 \% \text {, 4) } \\
\text { maintenance of tree cover around } 58 \% \text { while } \\
\text { thinning at the same time as cork extractions, 5) } \\
\text { increase tree density in agroforest stands up to 120 } \\
\text { trees/ha when tree cover is below } 40 \% \text {, 6) } \\
\text { maintenance of tree cover around } 40 \% \text { while } \\
\text { thinning at the same time as cork extraction. }\end{array}$ \\
\hline $\begin{array}{l}\text { LNF } \\
\text { Portugal }\end{array}$ & $\begin{array}{l}\text { Rotation length = } 60 \text { years, } \\
\text { thinnings following the } \\
\text { willson factor (every } 5 \\
\text { years) }\end{array}$ & $\begin{array}{l}\text { Different prescriptions were automatically } \\
\text { constructed by combining changes in rotation } \\
\text { lengths, and shrub removals for maritime pine } \\
\text { stands. New rotation lengths ranged from } 55 \text { to } 100 \\
\text { years and number of shrub removals ranged from } \\
1 \text { to } 3 \text { during the rotation. }\end{array}$ \\
\hline $\begin{array}{l}\text { Montafon, Eastern } \\
\text { Alps of Austria }\end{array}$ & $\begin{array}{l}\text { Maintain timber production } \\
\text { and protective services } \\
\text { against gravitational } \\
\text { hazards }\end{array}$ & $\begin{array}{l}\text { Switch from BAU to management approaches } \\
\text { including the introduction of admixed tree species, } \\
\text { intensified harvesting to reduce standing stock, } \\
\text { gaining control of browsing by game species }\end{array}$ \\
\hline $\begin{array}{lr}\text { Northern } & \text { Boreal, } \\
\text { Joensuu } & \text { in } \\
\text { Finland } & \end{array}$ & $\begin{array}{l}\text { Even-aged management } \\
\text { system used for Scots pine, } \\
\text { Norway spruce and birch, } \\
\text { with rotation of } 60-100 \\
\text { years with regular thinning }\end{array}$ & $\begin{array}{l}\text { if timber prices vary, it is usually beneficial to delay } \\
\text { clear-felling whether or not there is a climate- } \\
\text { induced trend in tree growth. In mixed stands, there } \\
\text { will be more alternatives for the adaptation of } \\
\text { management, as the preference for tree species } \\
\text { can be changed over time based on their growth } \\
\text { and the prices of the different assortments. }\end{array}$ \\
\hline $\begin{array}{l}\text { Swiss Beech } \\
\text { forests }\end{array}$ & $\begin{array}{l}\text { Even-aged management } \\
\text { system, with varying } \\
\text { rotation of } 60-120 \text { years }\end{array}$ & $\begin{array}{l}\text { The optimal set of thinning activities (intensity, } \\
\text { regime) over time }\end{array}$ \\
\hline
\end{tabular}




\begin{tabular}{|c|c|c|}
\hline $\begin{array}{ll}\text { Veluwe } & \text { The } \\
\text { Netherlands } & \end{array}$ & $\begin{array}{l}\text { Multifunctional forest } \\
\text { management based on the } \\
\text { tree species diversity }\end{array}$ & $\begin{array}{l}\text { The optimal admixture of different tree species } \\
\text { including exotic species e.g. Douglas fir and } \\
\text { change in harvesting level }\end{array}$ \\
\hline $\begin{array}{l}\text { Pre-Pyrenees of } \\
\text { Catalonia (Spain) }\end{array}$ & Absence of management & $\begin{array}{l}\text { The optimal sequence of thinning to reduce fire risk } \\
\text { and dispersal and decide upon the optimal } \\
\text { management systems (e.g. shelter-wood, selection } \\
\text { cuttings) }\end{array}$ \\
\hline $\begin{array}{l}\text { Panagyurishte, } \\
\text { Bulgaria }\end{array}$ & $\begin{array}{l}\text { Coppice, coppice with } \\
\text { standard, standard forests }\end{array}$ & $\begin{array}{l}\text { Adapting transformation of coppice to coppice with } \\
\text { standard forest, conversion of pure Pine } \\
\text { plantations to mixed Pine-broadleaves forests, and } \\
\text { maintaining mixed broadleaved forests }\end{array}$ \\
\hline $\begin{array}{l}\text { Carpathian, } \\
\text { Romania }\end{array}$ & $\begin{array}{l}\text { Even-aged and uneven- } \\
\text { aged forests of beech, } \\
\text { spruce or mixture thereof }\end{array}$ & $\begin{array}{l}\text { A1: intensive thinning }(15 \%>20 \%>25 \% \text { of basal } \\
\text { area) } \\
\text { A2: starting thinning sooner }(30>25 \text { years old }) \\
\text { A3: reduce reference age of harvesting trees } \\
(120>100)\end{array}$ \\
\hline $\begin{array}{l}\text { Høvild Forest, } \\
\text { Denmark }\end{array}$ & $\begin{array}{l}\text { Transformation of even- } \\
\text { aged monocultures into } \\
\text { near-natural forests }\end{array}$ & $\begin{array}{l}\text { optimal transformation to mixed conifers- } \\
\text { broadleaves by: } \\
\text { A1: an active strategies: selective/gradual } \\
\text { harvesting is initiated before the optimal target } \\
\text { diameter is reached } \\
\text { A2: a passive strategies: selective/gradual } \\
\text { harvesting is initiated at the optimal rotation age } \\
\text { A3: strict target diameter strategies where trees } \\
\text { are harvested when reaching the optimal target } \\
\text { diameter }\end{array}$ \\
\hline Wales & $\begin{array}{l}\text { low-impact silviculture } \\
\text { system, and short-rotation } \\
\text { forestry with the same } \\
\text { species over time and } \\
\text { thinning of trees exposed to } \\
\text { a high wind risk from age } \\
20 \text {, clear cut at rotation age } \\
100 \text { years. }\end{array}$ & $\begin{array}{l}\text { A1: natural reserve (species diversity DIV), } \\
\text { species change to the most suitable climate-soil } \\
\text { species allowed, rotation age is } 100 \text { years } \\
\text { A2: short rotation forestry (SRF), transformation to } \\
\text { shorter rotation at the age } 50 \text { except poor quality } \\
\text { sites } \\
\text { A3: low impact silvicultural systems (LISS), heavy } \\
\text { thinning (half of basal area) at the age } 50 \text { and } \\
\text { conversion to close to nature forestry if forest is } \\
\text { very vulnerable to wind. And even-aged forestry if } \\
\text { not. Rotation age stays } 100 \text { years. }\end{array}$ \\
\hline
\end{tabular}


Appendix 4 Adaptive decisions analysis.

Table A4.1 Summary of management objectives, techniques and derived decisions on forest management strategies under climate change.

\begin{tabular}{|c|c|c|c|}
\hline Case study area & $\begin{array}{l}\text { Objectives } \quad \& \\
\text { Constraints }\end{array}$ & Decision & Techniques \\
\hline Black Forest & $\begin{array}{l}\text { Max. Biomass } \\
\text { production }\end{array}$ & $\begin{array}{l}\text { Always change BAU to an } \\
\text { alternative } A 1-3 \\
\text { s. t. CC scenarios and Beliefs }\end{array}$ & $\begin{array}{l}\text { Cost-benefit } \\
\text { analysis }\end{array}$ \\
\hline Black Forest & Min Windthrow & $\begin{array}{l}\text { Switch from BAU to A2 after } 10 \\
\text { years (2020) }\end{array}$ & $\begin{array}{l}\text { Cost-benefit } \\
\text { analysis }\end{array}$ \\
\hline LNF & Max FV, & $\begin{array}{l}\text { Longer rotation lengths are } \\
\text { selected }\end{array}$ & Stochastic MIP \\
\hline CHAMUSCA & Max FV & $\begin{array}{l}\text { Longer rotation lengths are } \\
\text { selected }\end{array}$ & LP and MIP \\
\hline CHAMUSCA & $\begin{array}{l}\text { Max Cork } \\
\text { Production } \\
\text { considering 1) even } \\
\text { flow as much as } \\
\text { possible or 2) } \\
\text { concentrating } \\
\text { extractions as much } \\
\text { as possible }\end{array}$ & $\begin{array}{l}\text { Change some cork } \\
\text { extraction cycles to } 10 \text { or } \\
11 \text { years. Change about } \\
20 \% \text { of the stands if not } \\
\text { consider even flow. Change } \\
\text { about } 39 \% \text { if considering } \\
\text { even flow. The above } \\
\text { decisions need to occur } \\
\text { simultaneously with stand } \\
\text { density maintenance at } \\
58 \% \text { and } 40 \% \text { for forests } \\
\text { and agroforests } \\
\text { respectively. }\end{array}$ & $\begin{array}{l}\text { Mixed Integer } \\
\text { Goal } \\
\text { Programming }\end{array}$ \\
\hline $\begin{array}{l}\text { Northern Boreal, } \\
\text { Joensuu }\end{array}$ & Max NPV & $\begin{array}{l}\text { Continuous diversity of tree } \\
\text { species and timber } \\
\text { assortments. }\end{array}$ & $\begin{array}{l}\text { Optimization of AFM } \\
\text { in reaction to the } \\
\text { actual state of } \\
\text { nature }\end{array}$ \\
\hline $\begin{array}{l}\text { Northern Boreal, } \\
\text { Joensuu }\end{array}$ & $\begin{array}{l}\text { Max NPV with } \\
\text { considering wind risk }\end{array}$ & $\begin{array}{l}\text { Continuous diversity of tree } \\
\text { species and timber } \\
\text { assortments. }\end{array}$ & $\begin{array}{l}\text { Optimization of AFM } \\
\text { in reaction to the } \\
\text { actual state of } \\
\text { nature }\end{array}$ \\
\hline
\end{tabular}




\begin{tabular}{|c|c|c|c|}
\hline Switzerland & Max NPV & $\begin{array}{l}\text { Change in thinning intensity } \\
\text { and regime depending on the } \\
\text { site class }\end{array}$ & $\begin{array}{l}\text { Optimization of AFM } \\
\text { and BAU for } \\
\text { comparison }\end{array}$ \\
\hline $\begin{array}{l}\text { Veluwe in the } \\
\text { Netherlands }\end{array}$ & $\begin{array}{l}\text { Max Biomass } \\
\text { production }\end{array}$ & $\begin{array}{l}\text { Change the forest } \\
\text { management regime i.e. } \\
\text { admixture of tree species and } \\
\text { harvest level }\end{array}$ & $\begin{array}{l}\text { Cost-benefit } \\
\text { analysis among } \\
\text { BAU, AFM and } \\
\text { Conservation }\end{array}$ \\
\hline $\begin{array}{l}\text { Pre-Pyrenees of } \\
\text { Catalonia (Spain) }\end{array}$ & $\begin{array}{l}\text { Multiple objectives (e.g. } \\
\text { max. net income, fire- } \\
\text { adjusted net income, } \\
\text { mean fire safety) }\end{array}$ & $\begin{array}{l}\text { Active forest management } \\
\text { including low thinning, uneven- } \\
\text { aged forest systems (shelter- } \\
\text { wood, selective felling), Spatial } \\
\text { allocation of treatments }\end{array}$ & $\begin{array}{l}\text { Optimization by } \\
\text { simulated Annealing } \\
\text { using a cost-benefit } \\
\text { objective function } \\
\text { and s. t. fire risk }\end{array}$ \\
\hline $\begin{array}{l}\text { Panagyurishte, } \\
\text { Bulgaria }\end{array}$ & $\begin{array}{l}\text { Max. annual growth } \\
\text { increment, min. } \\
\text { mortality }\end{array}$ & $\begin{array}{l}\text { Decreasing harvested timber } \\
\text { volume per hectare, focus on } \\
\text { construction timber production, } \\
\text { erosion control and non-timber } \\
\text { production e.g. recreation }\end{array}$ & $\begin{array}{l}\text { Growth and Yield } \\
\text { analysis considering } \\
\text { provisioning of } \\
\text { environmental } \\
\text { services and forest } \\
\text { risks }\end{array}$ \\
\hline $\begin{array}{l}\text { Carpathian, } \\
\text { Romania }\end{array}$ & $\begin{array}{l}\text { Max. biomass } \\
\text { production, and stand } \\
\text { density }\end{array}$ & $\begin{array}{l}\text { Frequency of harvesting } \\
\text { increased and resulted in } \\
\text { younger regional forest } \\
\text { structure to avoid any decrease } \\
\text { in forest biomass level because } \\
\text { of forest aging }\end{array}$ & $\begin{array}{l}\text { Growth and Yield } \\
\text { analysis considering } \\
\text { biomass production } \\
\text { and stands age } \\
\text { distribution }\end{array}$ \\
\hline $\begin{array}{l}\text { Høvild Forest, } \\
\text { Denmark }\end{array}$ & $\begin{array}{l}\text { Max. Expectation } \\
\text { values } \\
\text { s.t. wind throw risk }\end{array}$ & $\begin{array}{l}\text { large harvest and income in } \\
\text { initially over-mature forest } \\
\text { structure for all AFMs and } \\
\text { superiority of A } 1 \text { for wind throw } \\
\text { vulnerability reduction }\end{array}$ & $\begin{array}{l}\text { Cost-benefit } \\
\text { analysis }\end{array}$ \\
\hline Wales, UK & Mixture of indicators & $\begin{array}{l}\text { Low impact silviculture systems } \\
\text { on suitable sites, and the } \\
\text { promotion of a greater range of } \\
\text { tree species }\end{array}$ & Scenario analysis \\
\hline
\end{tabular}

FV: Forest Value, LP: Linear Programming, DP: Dynamic programming, MIP: Mixed Integer Programming, NPV net present value 